\title{
Inflammatory Markers for Arterial Stiffness in Cardiovascular Diseases
}

\author{
loana Mozos ${ }^{1,2 *}$, Clemens Malainer ${ }^{3}$, Jarosław Horbańczuk ${ }^{4}$, Cristina Gug ${ }^{5}$, Dana Stoian ${ }^{6}$, \\ Constantin Tudor Luca ${ }^{7}$ and Atanas G. Atanasov ${ }^{4,8,9 *}$ \\ 'Department of Functional Sciences, "Victor Babes" University of Medicine and Pharmacy, Timisoara, Romania, ${ }^{2}$ Center for \\ Translational Research and Systems Medicine, "Victor Babes" University of Medicine and Pharmacy, Timisoara, Romania, \\ ${ }^{3}$ Independent Researcher, Vienna, Austria, ${ }^{4}$ The Institute of Genetics and Animal Breeding, Polish Academy of Sciences, \\ Jastrzębiec, Poland, ${ }^{5}$ Department of Microscopic Morphology, "Victor Babes" University of Medicine and Pharmacy, \\ Timisoara, Romania, 6 2nd Department of Internal Medicine, "Victor Babes" University of Medicine and Pharmacy, Timisoara, \\ Romania, 'Department of Cardiology, "Victor Babes" University of Medicine and Pharmacy, Timisoara, Romania, \\ ${ }^{8}$ Department of Pharmacognosy, Faculty of Life Sciences, University of Vienna, Vienna, Austria, ${ }^{9}$ Department of Vascular \\ Biology and Thrombosis Research, Center for Physiology and Pharmacology, Medical University of Vienna, Vienna, Austria
}

\section{OPEN ACCESS}

Edited by: Jixin Zhong,

Case Western Reserve University, United States

Reviewed by: Xuhui Feng,

Indiana University System, United States Ding Xinchun,

Indiana University, Purdue University Indianapolis, United States Xiaojing Yue,

La Jolla Institute for Allergy and Immunology, United States

*Correspondence: Ioana Mozos

ioana_mozos@yahoo.com;

Atanas G. Atanasov a.atanasov.mailbox@gmail.com

Specialty section: This article was submitted to Inflammation,

a section of the journal

Frontiers in Immunology

Received: 20 June 2017 Accepted: 15 August 2017 Published: 31 August 2017

Citation:

Mozos I, Malainer C, Horbańczuk J, Gug C, Stoian D, Luca CT and Atanasov AG (2017) Inflammatory Markers for Arterial Stiffness in

Cardiovascular Diseases.

Front. Immunol. 8:1058. doi: 10.3389/fimmu.2017.01058
Arterial stiffness predicts an increased risk of cardiovascular events. Inflammation plays a major role in large arteries stiffening, related to atherosclerosis, arteriosclerosis, endothelial dysfunction, smooth muscle cell migration, vascular calcification, increased activity of metalloproteinases, extracellular matrix degradation, oxidative stress, elastolysis, and degradation of collagen. The present paper reviews main mechanisms explaining the crosstalk between inflammation and arterial stiffness and the most common inflammatory markers associated with increased arterial stiffness, considering the most recent clinical and experimental studies. Diverse studies revealed significant correlations between the severity of arterial stiffness and inflammatory markers, such as white blood cell count, neutrophil/lymphocyte ratio, adhesion molecules, fibrinogen, C-reactive protein, cytokines, microRNAs, and cyclooxygenase-2, in patients with a broad variety of diseases, such as metabolic syndrome, diabetes, coronary heart disease, peripheral arterial disease, malignant and rheumatic disorders, polycystic kidney disease, renal transplant, familial Mediterranean fever, and oral infections, and in women with preeclampsia or after menopause. There is strong evidence that inflammation plays an important and, at least, partly reversible role in the development of arterial stiffness, and inflammatory markers may be useful additional tools in the assessment of the cardiovascular risk in clinical practice. Combined assessment of arterial stiffness and inflammatory markers may improve non-invasive assessment of cardiovascular risk, enabling selection of high-risk patients for prophylactic treatment or more regular medical examination. Development of future destiffening therapies may target pro-inflammatory mechanisms.

Keywords: inflammatory markers, arterial stiffness, inflammation, cardiovascular diseases, cardiovascular risk factors

\section{INTRODUCTION}

The elasticity and distensibility of arteries maintain a relatively constant blood pressure, despite the pulsating nature of the blood flow by every heartbeat. Arteries expand by receiving blood ejected from the heart during systole and expel it to the periphery during diastole to supply the peripheral circulation with a steady flow of blood during both cardiac cycles (1). However, as a 
hallmark of normal aging and apart from that also in association with many diseases compliance and distensibility of arteries decrease and the term "arterial stiffness" is used to qualitatively indicate these decreased elastic vessel wall properties (2). An increased arterial stiffness leads to a decreased buffer capacity of the arteries and an increase in pulse pressure (PP) and pulse wave velocity (PWV), causing an early return of the reflected waves and thereby an augmentation of late systolic pressure (3). As a consequence, the left ventricle has to generate an extra workload to overcome the augmented pressure, which is associated with an increased demand of oxygen and in the long-term development of left ventricular hypertrophy and heart failure (4). Insufficient arterial compliance furthermore transmits the increased pulsatile pressure deeper into the periphery and damages microvasculature of distal-end organ systems, especially in the kidney and the brain (5).

Arterial stiffness is considered a growing epidemic, associated with an increased risk of cardiovascular events (6-8). It is an early sign of structural and functional changes of the vessel wall and an independent predictor of cardiovascular disorders, that arise as a consequence of arteriosclerosis and atherosclerosis $(9,10)$. Several other chronic disorders may also contribute to an increase in arterial stiffness. The most important vascular changes related to increased arterial stiffness are vascular fibrosis due to collagen deposition, fragmentation of elastic fibers (elastolysis), crosslinking of collagen and elastin fibers by advanced glycation end products, and extensive vessel wall calcification (11-14). PWV and augmentation indices are commonly used measures of arterial stiffness and wave reflection.

Local inflammation is a complex non-specific protective response of vascular tissue to injury in order to eliminate its cause. Atherosclerosis is considered an inflammatory disease, because low-grade inflammation contributes to all phases of atherosclerosis development, starting with the initial phase of endothelial dysfunction, up to the formation of the mature atherosclerotic plaque, disruption of atherosclerotic injuries, precipitation of plaque rupture, and the acute thrombotic complications of atheroma $(11,15-19)$. Increased levels of inflammatory markers, e.g., erythrocyte sedimentation rate (ESR), C-reactive protein (CRP), and interleukin-6 (IL-6) have been associated with cardiovascular mortality and morbidity (19). As induction of experimental inflammation increases arterial stiffness, a cause-effect relationship between the two can be established, and anti-inflammatory therapy may, at least in part, reduce arterial stiffness $(20,21)$.

Both markers of inflammation and arterial stiffness are predictors of cardiovascular events (19). Understanding the mechanisms linking inflammation and arterial stiffness enables to apply a suitable anti-inflammatory therapy in order to reduce cardiovascular risk in several conditions.

Also, systemic inflammation has been shown to increase the risk of cardiovascular disease by accelerating atherosclerosis, destabilizing plaques, impairing endothelial function, or causing premature arterial stiffness (21-23). Considering that arterial stiffness is often the result of integrating the damage of cardiovascular risk factors on the arterial wall over a long period of time, prophylactic cardiovascular measures may open a window of opportunity to prevent the occurrence of cardiovascular disease even before first symptoms become immanent, which is an important aspect of health care in the ever-aging Western societies (10).

It is the aim of the present paper to highlight the role of inflammation on large vessels in view of arterial stiffness, review the main mechanisms explaining the crosstalk between inflammation and arterial stiffness and the most common inflammatory markers associated with an increased arterial stiffness, considering the most recent clinical and experimental studies published in biomedical research. Understanding the role of inflammation in the pathophysiology of arterial stiffness is crucial in order to enable development of new therapies by modulation of inflammatory pathways, which have been identified as major targets for the treatment of arterial stiffness.

\section{MECHANISMS UNDERLYING THE LINK BETWEEN INFLAMMATION AND ARTERIAL STIFFNESS}

Cardiovascular risk factors induce a state of inflammation able to impair vascular function (15). Activation of vascular smooth muscle cells (VSMCs) due to cardiovascular risk factors increases synthesis of the extracellular matrix and enables their migration from the vascular media to the intima (24).

Atherosclerosis is a syndrome caused due to chronic inflammatory interactions of white blood cells (WBCs) in the wall of arteries, and therefore, plasma inflammatory markers are considered potential tools for cardiovascular risk prediction $(15,25,26)$. The mechanisms underlying the association between inflammation and atherosclerosis are generally complex and multifaceted (17). An increase in circulating inflammatory mediators enables WBC infiltration into arteries (27). Macrophage activation is associated with the release of inflammatory cytokines and reactive oxygen species to amplify the inflammatory reaction, and after transformation into foam cells, they undergo necrosis, further release inflammatory stimuli, and are thereby creating the necrotic core of advanced lesions (28). The onset of the inflammatory cascade, in acute and chronic inflammatory diseases and systemic subclinical low-grade inflammation, impairs endothelial function and the mechanical properties of the arteries (17). Endothelial cells (ECs), through reduction of bioavailability of nitric oxide (NO) and an increase of endothelin-1 due to inflammation, contribute to arterial stiffening and progressing arterial stiffing, in turn, further impairs endothelial function, thus inducing a vicious cycle $(1,3,29)$. Decreased NO also promotes leukocyte adhesion (15). Additionally, endothelial dysfunction is also associated with activation of ECs which become pro-inflammatory, increasing expression of adhesion molecules, produce monocyte chemoattractant protein-1 (MCP-1) and leukocyte transmigration and activation, involving cytokines $(13,15)$.

Antigen-presenting cells such as dendritic cells and effector $\mathrm{T}$ lymphocytes play an important role in the synthesis of proatherogenic cytokines, such as IL-2, IL-18, and interferon gamma, and are therefore also important in atherosclerotic plaque progression (30). A special role among proatherogenic 
cytokines has been attributed to IL-12 as its absence was shown to inhibit early, but not late, lesion development (30). In conclusion, activated endothelium contributes to the initiation and the perpetuation of vascular wall inflammation (17).

Furthermore, monocytes are attracted and recruited to the vessel wall, where they differentiate into macrophages and ingest oxidized LDL (oxLDL) via scavenger receptors or lectin-like oxidized low-density lipoprotein receptor 1 (LOX-1). In this context, it has been shown that overexpression of SIRT1 is able to decrease LOX-1 expression and prevent foam cell formation in a mouse model of atherogenesis regardless of serum lipid levels. The underlying mechanism for this effect was shown to rely on suppression of NFkB-signaling by deacetylating RelA/p65, thereby reducing LOX-1 expression and diminishing uptake of oxLDL and foam cell formation and consequently also arterial stiffness (31). Therefore, pharmacological activation of SIRT1 may also offer an attractive approach in the treatment of arterial stiffness. Exposure to several pro-inflammatory and proatherogenic stimuli has been shown in vivo to upregulate LOX-1 expression, which is the main oxLDL receptor (32), and also in humans, LOX-1 gene polymorphisms are associated with increased susceptibility to cardiovascular disease (33).

Vascular inflammation increases arterial stiffness also by enabling vascular fibrosis and smooth muscle cell proliferation (19). The cellular components of the arterial wall, the VSMCs, and ECs are involved in maintaining homeostatic balance of the arterial blood pressure (3). In addition, VSMC can also undergo transdifferentiation into an osteoblastic phenotype under inflammatory conditions enabling mineralization (phosphate uptake), and calcium deposition in the arterial media $(3,27)$. Inflammatory cells produce mediators such as cytokines and metalloproteinases that regulate cardiovascular remodeling (34). Activation of matrix metalloproteinases (MMPs), mediated by increased inflammatory markers, enable degradation of elastin and collagen of the vessel wall (18). Inflammation enables also plaque rupture and is thus further contributing to the occurrence of acute coronary syndromes (15).

Arteriosclerosis is the age-associated stiffening and dilation of arteries, accompanied by low-grade inflammation (35). Interestingly, in humans early signs of arterial aging (so called "fatty streaks") are already observable in children in their first decade, but it usually takes several decades for progression into a symptomatic disease (36). Arterial aging has been identified as a key mechanism enabling development and progression of cardiovascular and other chronic disorders and is heavily influenced by lifestyle factors (37). The chronic pro-inflammatory profile within aging arteries is characterized by impaired angiotensin II (AII), mineralocorticoid receptor, and endothelin-1 signaling with the result of increased activity and/or expression of downstream pro-inflammatory transcription factors, whereas levels/activity of protective factors become reduced (38). Also, the process of cellular senescence is suggested to be an important contributor to immunosenescence and "inflamm-aging" since senescent cells acquire a secretory phenotype, characterized by enhanced secretion of inflammatory modulators, such as monocyte chemoattractant protein-1 (MCP-1, which attracts invasion of smooth muscle cells), and cytokines, such as IL-1, IL-6, and IL-17 (39).
Pro-inflammatory cytokines enable platelet and endothelial activation, which is related to an increased risk of cardiovascular events (35). Vascular aging is also associated with an increased vascular smooth muscle tone, an increased activity of the reninangiotensin-aldosterone system, and an increase of oxidative stress, all of which contributes to arterial proinflammation and age-related arterial remodeling $(13,38)$. Further contributors to vascular aging are elevated levels of MMPs, calpain-1 (facilitating calcification), transforming growth factor beta-1 (increasing the production of extracellular matrix), amyloid deposition as medin, accumulation of fibronectin and cell adhesion proteins, increase of pro-inflammatory transcription factors as well as increased synthesis of advanced glycation end products, and decreased arterial expression and activity of sirtuins $(13,38)$. The loss of balance between oxidative and antioxidative systems results in increased production of reactive oxygen species leading to inactivation of $\mathrm{NO}$ and increased nitrosative stress which contributes to age-associated endothelial dysfunction $(13,40)$. The increased degradation of elastin fibers is mediated by activation of MMPs and serine proteinases, accompanied by a decreased activity of its endogenous inhibitor TIMP-2 (tissue inhibitor of metalloproteinases 2) (18). MMP is involved in the occurrence of uncoiled, stiffer collagen due to its collagenolytic activity and degradation of the basement membranes $(6,18)$. The increased MMPs activity is mediated by increased activity of cell adhesion molecules and cytokines $(41,42)$. Increased VSMC migration, proliferation and senescence, extracellular matrix deposition, matrix calcification, amyloidization and glycation, and elastin fracture disrupt the endothelium and thus, foster vascular aging (38).

Systemic subclinical low-grade inflammation is closely related to most cardiovascular risk factors, especially to hypertension and diabetes, to all stages of atherosclerosis, to arteriosclerosis and to impaired arterial elastic properties $(17,43,44)$. Reduction in inflammation can decrease arterial stiffness, which was demonstrated among others in patients with rheumatoid arthritis (RA) undergoing therapy with anti-tumor necrosis factor- $\alpha$ (TNF- $\alpha$ ) agents (21). Also, statins and other cholesterol-reducing agents are reported in numerous studies to have beneficial effects on wave reflection and aortic stiffness reduction in several patient groups $(45,46)$.

Pulse wave velocity inversely correlates with arterial distensibility, and an impaired arterial distensibility alters blood pressure, flow dynamics, increases afterload, and impairs coronary perfusion (27). Concluding, inflammation plays a major role in large artery stiffening, in the context of cardiovascular risk factors, atherosclerosis, arteriosclerosis, endothelial dysfunction, smooth muscle cell migration, vascular calcification, increased activity of metalloproteinases, extracellular matrix degradation, oxidative stress, elastolysis, degradation of collagen, and occurrence of uncoiled, stiffer collagen. Overview of relevant inflammatory markers associated with arterial stiffness and their crosstalk with other related conditions is presented in Figure 1.

\section{WBCs AND ARTERIAL STIFFNESS}

An increased WBC has been associated with arterial stiffness and other atherosclerotic events in multiple studies (47). Chronic 


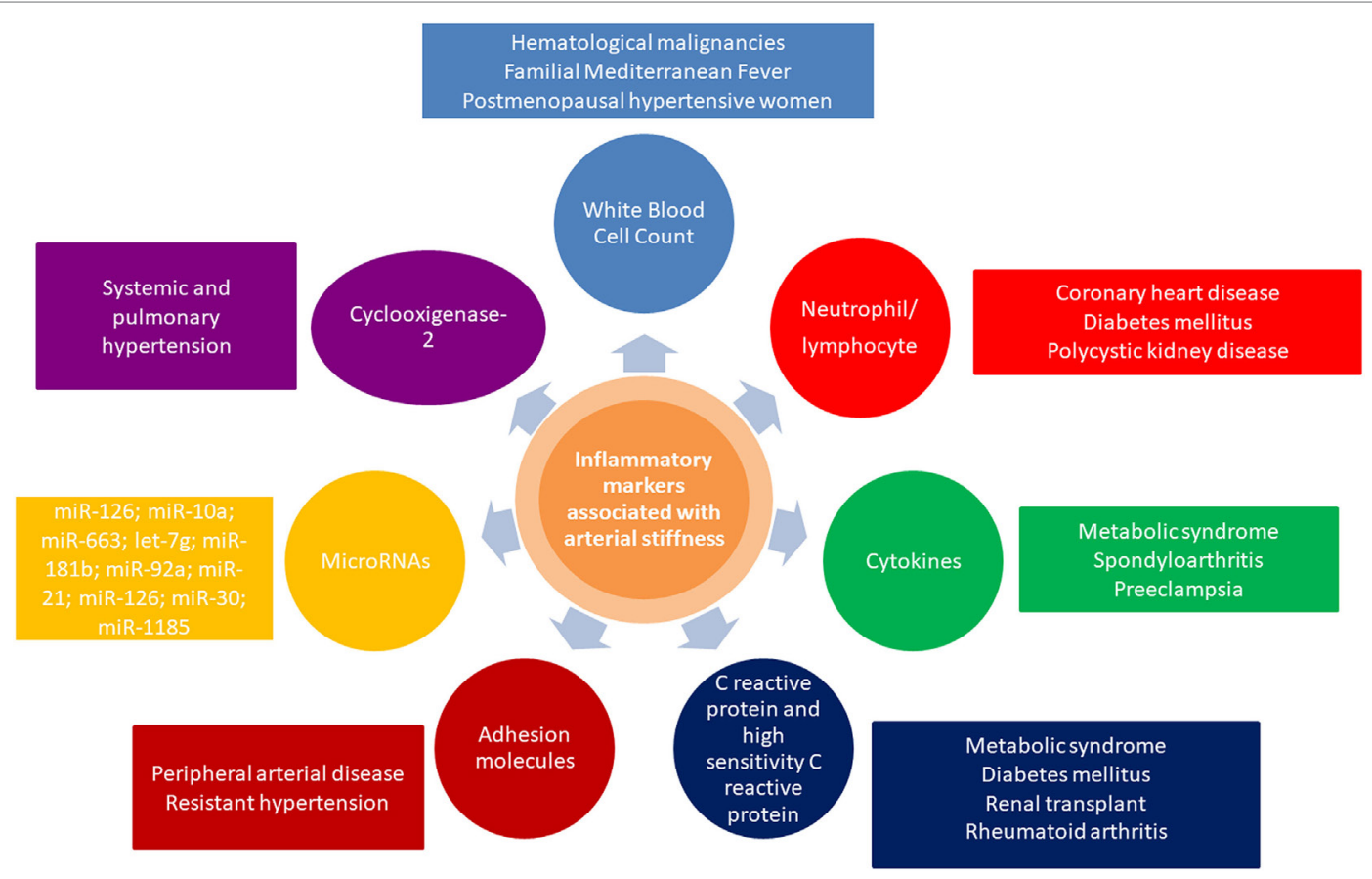

FIGURE 1 | Overview of inflammatory markers associated with arterial stiffness and their crosstalk with other related conditions.

low-grade inflammation in the arterial wall may play an important role in the initiation and progression of cardiovascular diseases, considering that stimulated WBCs adhere to the vascular endothelium and easily penetrate the intima, causing capillary leukostasis and increase in vascular resistance (19). Additionally, stimulated WBCs release some hydrolytic enzymes, cytokines, and growth factors, which have the potential to induce further vascular damage (19). Total leukocyte count enables a low cost, widely available assessment of inflammatory status (19). However, there has been a recent shift away from total WBC count toward differential white cell count as particular WBC types (e.g., neutrophils, lymphocytes, or monocytes) have been suggested to be stronger predictors of cardiovascular risk (48). This is among others because total WBC is influenced by ethnic origin and gender, which is complicating the definition of reference ranges for whole populations (49). An elevated neutrophil count, which is another marker of systemic inflammation, has been suggested as a prognostic marker of cardiovascular disease particularly in hypertensive postmenopausal women (50).

The distribution of WBC subtypes is regulated by the autonomic nervous system since lymphocytes have cholinergic receptors and granulocytes have adrenergic receptors $(44,51)$. Consequently, the number and function of granulocytes are stimulated by sympathetic nerves, whereby parasympathetic nerves stimulate those of lymphocytes (51). Sympathetic overactivation may be associated with endothelial dysfunction (44).

Mozos et al. found correlations and associations between arterial stiffness and neutrophil monocyte, lymphocyte, and WBC count, respectively, in patients with hematologic malignancies and solid tumors $(52,53)$. Increased WBC may be a consequence of the hematologic malignancy, and also a marker of systemic inflammation (47). In chronic granulocytic leukemia, significant associations were found between WBC and arterial stiffness, which are probably related to the increased blood viscosity caused by the high concentration of WBCs (54). Elevated blood viscosity increases vascular shear stress, enabling rapid growth of the atherosclerotic plaque and increasing its instability (55).

Gomez-Sanchez et al. report a positive correlation between central augmentation index (CAIx) and monocyte count only in women, and between neutrophil count and intima-media thickness (IMT) in men, in a study including 500 subjects with intermediate risk (56). Gender differences may be explained by higher IMT in men and higher CAIx in women, the influence of sex steroids on vascular function and the influence of anthropometric factors (e.g., differences in the distribution of body fat, average height, as well as aortic length) (56).

In patients with familial Mediterranean fever (FMF), which is an autosomal recessive disorder restricted to certain ethnic groups, characterized by recurrent inflammatory febrile attacks of the serosal and synovial membranes; the ongoing and recurring inflammatory state is associated with an increased cardiovascular risk and an elevated arterial stiffness $(57,58)$. The inflammatory process in FMF results from malfunction of the MEFV gene located on 16p and is associated with uncontrolled inflammatory reactions due to the absence of an inhibitor of $\mathrm{C} 5 \mathrm{a}$ and excessive release of tumor necrosis factor and interleukin-1 $(57,59)$. The MEFV gene encodes mutated protein pyrin, essential in the innate immune system and inflammasome (59). Arterial stiffness (assessed via PWV) was correlated with the severity of inflammation and several inflammatory markers, including WBC, CRP, 
ESR, fibrinogen, and neutrophil/lymphocyte ratio (NLR), and not to the genetic mutation (58). This is in contrast to earlier research where correlations of PWV with leukocyte count but not with CRP in patients with FMF were found (57). This discrepancy might possibly be explainable by a different dosage regime of colchicine of study participants, since colchicine is reported to alter levels of CRP in patients using the drug (60) or confounders that are not known yet or such that were not considered. Sustained inflammation functionally impairs microcirculation, which poses a reason for the increased cardiovascular risk in patients with FMF (58). The increase in the arterial stiffness during attacks might be related to the released cytokines, and subsequent inflammation-induced vasoconstriction (58). Further studies are needed to assess the relationship between arterial stiffness and interleukin- 1 and TNF- $\alpha$ in patients with Mediterranean fever.

In conclusion, several studies report a link between arterial stiffness and WBC or leukocyte subtypes, respectively, in particular in patients with hematologic malignancies or FMF, and in postmenopausal women with hypertension (Table 1) (50, 52, 57, 58). It is also important to consider that arterial stiffness modulates the functional responses of $\mathrm{WBC}$, as experimental studies have demonstrated that the mechanical properties of the substrate may influence migration of neutrophils: they migrate more slowly due to significantly larger traction stresses on the stiffer substrates, but more persistently, enabling movement on greater distances over time despite slower speeds (61).

Neutrophil/lymphocyte ratio, the ratio between neutrophil and lymphocyte count, is available in routine complete blood count analyses and may be used as a cost-effective biomarker of inflammation, atherosclerotic progression and systemic predictor of cardiovascular complications, especially in context of myocardial infarction and coronary heart disease $(19,62)$. Chronic low-grade inflammation or subclinical inflammation as indicated by the NLR plays a role in diabetes, obesity, dyslipidemia, hypertension, metabolic syndrome, and endothelial dysfunction (62-64). A higher NLR despite normal WBC shows a higher risk of atherosclerotic disease (65). NLR is a more powerful predictor of cardiovascular disease than any other leukocyte subtype (66). This might be explainable due to the fact that it is less likely to be altered by various physiological conditions (e.g., dehydration or recent exercise) and also, more importantly, that NLR is the ratio of two different, but complementary immune pathways (48).

Inflammation plays an important role in diabetes-induced cardiovascular events related to atherosclerotic injuries. NLR was correlated with aortic stiffness in patients with type 1 diabetes in a study including 76 subjects with type 1 diabetes (19) and in patients with type 2 diabetes mellitus (Table 2) (67).

Coronary heart disease was associated with elevations in inflammatory markers and changes in leukocyte subset distribution $(68,69)$. Neutrophil count and NLR are promising markers of the presence and severity of coronary heart disease $(70,71)$. Endothelial dysfunction in coronary arteries may result from the neutrophil-endothelium interaction, and the increased neutrophil count may accelerate endothelial abnormalities $(69,72)$. A higher NLR was independently associated with arterial stiffness and coronary calcium score in a large study including 849 Korean adults, revealing that higher NLR may be a useful additional measure for assessing cardiovascular risks (73). Yaman et al. evaluated 103 patients, without a previous history of coronary artery disease (CAD), who presented with STEMI without hemodynamic compromise and underwent successful primary percutaneous coronary intervention. The authors report improvement of arterial stiffness associated with a decrease in NLR (69).

TABLE 1 | White blood cell (WBC) count and arterial stiffness.

\begin{tabular}{|c|c|c|}
\hline Study population & Findings & Reference \\
\hline $\begin{array}{l}69 \text { consecutive familial Mediterranean } \\
\text { fever (FMF) patients and } 35 \text { controls }\end{array}$ & $\begin{array}{l}\text { Pulse wave velocity (PWV) was correlated to serum C-reactive protein (CRP), WBC, erythrocyte } \\
\text { sedimentation rate, fibrinogen, and neutrophil/lymphocyte ratio }\end{array}$ & Cakar et al. (58) \\
\hline $\begin{array}{l}29 \text { patients with hematologic } \\
\text { malignancies ( } 8 \text { with multiple myeloma, } \\
2 \text { with Hodgkin's lymphoma, } 11 \text { with } \\
\text { non-Hodgkin's lymphoma, } 6 \text { with } \\
\text { myelodysplastic syndrome, and } 2 \text { with } \\
\text { chronic myeloid leukemia) }\end{array}$ & $\begin{array}{l}\text { An inverse correlation was found between PWV and neutrophil count }(r=-0.45) \text {. Multiple } \\
\text { regression analysis found significant associations between augmentation index (Al) and PWV, and } \\
\text { WBC and platelet count, respectively }\end{array}$ & Mozos and Mihaescu (52) \\
\hline $\begin{array}{l}20 \text { patients with solid tumors (colon, lung, } \\
\text { renal, laryngeal, pancreas, mammary } \\
\text { and testicular cancer, and malignant } \\
\text { melanoma) and } 26 \text { healthy controls }\end{array}$ & $\begin{array}{l}\text { Significant higher values were obtained for PWV, Al and central hemodynamic variables in cancer } \\
\text { patients compared to healthy controls. The best correlation was found between Al and neutrophil } \\
\text { count and WBC, respectively. PWV as a measure of arterial stiffness was significantly associated } \\
\text { with neutrophilia, monocytosis, and lymphopenia. Al was significantly associated with neutrophilia }\end{array}$ & Mozos and Mihaescu (53) \\
\hline $\begin{array}{l}500 \text { subjects included in the MARK } \\
\text { study, aged } 35-74 \text { years }\end{array}$ & $\begin{array}{l}\text { Monocyte count was positively correlated with central augmentation index (CAlx) in women, also } \\
\text { after adjusting for age and other confounders }\end{array}$ & Gomez-Sanchez et al. (56) \\
\hline $\begin{array}{l}886 \text { postmenopausal women with } \\
\text { hypertension }\end{array}$ & $\begin{array}{l}\text { A direct relationship between neutrophil count and 24-h ambulatory pulse pressure (PP) was } \\
\text { observed. Increased arterial stiffness, as reflected in high values of 24-h ambulatory PP, is an } \\
\text { adverse prognostic marker in postmenopausal women with hypertension and can be used as an } \\
\text { additional correlate for systemic inflammation }\end{array}$ & Angeli et al. (50) \\
\hline $\begin{array}{l}23 \text { colchicine-treated patients with FMF } \\
\text { and } 23 \text { age- and sex-matched controls }\end{array}$ & $\begin{array}{l}\text { PWV was slightly higher in colchicine-treated FMF patients than in control subjects }(P=0.05) \\
\text { and significantly correlated with age and leukocyte count, but no correlations between PWV and } \\
\text { CRP levels or blood pressure could be observed } \\
\text { PWV was furthermore found to be generally influenced by age and body mass index }\end{array}$ & Yildiz et al. (57) \\
\hline
\end{tabular}


TABLE 2 | Neutrophil/lymphocyte ratio (NLR) and arterial stiffness.

\begin{tabular}{|c|c|c|}
\hline Study population & Findings & Reference \\
\hline $\begin{array}{l}103 \text { patients with STEMI who underwent successful } \\
\text { primary percutaneous coronary intervention }\end{array}$ & $\begin{array}{l}\text { Aortic velocity propagation (AVP) values improved after successful treatment in STEMI } \\
\text { patients. The increment in AVP values was closely correlated with a decrement in NLR }\end{array}$ & Yaman et al. (69) \\
\hline $\begin{array}{l}145 \text { consecutive patients admitted with stable } \\
\text { angina pectoris or acute coronary syndrome (ACS) }\end{array}$ & $\begin{array}{l}\text { Augmentation index and pulse wave velocity (PWV) were positively associated with NLR. NLR } \\
\text { might be used to risk-stratify patients, considering arterial stiffness in patients with coronary } \\
\text { heart disease, especially in the presence of ACS }\end{array}$ & Tanindi et al. (44) \\
\hline $\begin{array}{l}76 \text { persons with type } 1 \text { diabetes and } 36 \text { healthy } \\
\text { controls }\end{array}$ & $\begin{array}{l}\text { The observed significant negative correlation between the NLR and markers of aortic stiffness } \\
\text { in patients with type } 1 \text { diabetes suggests a strong association between inflammation and } \\
\text { arterial stiffness }\end{array}$ & Ayhan et al. (19) \\
\hline $\begin{array}{l}402 \text { participants: } 133 \text { control subjects, } 138 \text { diabetic } \\
\text { subjects without diabetic retinopathy (DR) and } 131 \\
\text { patients with DR }\end{array}$ & $\begin{array}{l}\text { NLR and PWV were elevated both in type } 2 \text { diabetic and in DR. NLR could be independently } \\
\text { associated with PWV }\end{array}$ & Wang et al. (67) \\
\hline $\begin{array}{l}512 \text { postmenopausal women with a similar } \\
\text { socioeconomic background ( } 204 \text { patients with } \\
\text { osteoporosis, } 208 \text { controls) }\end{array}$ & $\begin{array}{l}\text { NLR and PWV were elevated in osteoporosis. Statistical analysis of collected data revealed a } \\
\text { significant correlation between NLR and PWV after adjusting for confounders in osteoporosis } \\
\text { patients, but not in the control group }\end{array}$ & Yu et al. (66) \\
\hline $\begin{array}{l}52 \text { autosomal dominant polycystic kidney disease } \\
\text { patients and } 25 \text { controls }\end{array}$ & $\begin{array}{l}\text { Pentraxin } 3 \text { and C-reactive protein were not correlated with arterial elasticity, while NLR was } \\
\text { significantly negatively correlated with large artery elasticity index }\end{array}$ & Gul et al. (75) \\
\hline 849 Korean adults in a health examination program & A higher NLR was independently associated with arterial stiffness and coronary calcium score & Park et al. (73) \\
\hline
\end{tabular}

In a recent study, NLR has also been correlated with coronary artery calcium score, which is an independent risk factor for coronary artery stenosis, in asymptomatic Korean males further underlining the high predictive value of NLR in the context of arterial stiffening (62). The beta-blocker nebivolol, which is known to possess anti-inflammatory effects mediated through increased NO-release in ECs, significantly lowered NLR in hypertensive patients (74). NLR has also been associated with arterial stiffness and high coronary calcium score in several previous studies (48). Early detection of abnormal NLR levels may be helpful for detecting increased arterial stiffness in patients with coronary heart disease, type 1 and 2 diabetes mellitus, osteoporosis, and polycystic kidney disease (Table 2) $(19,44,66,67,69,75)$.

\section{CYTOKINES AND ARTERIAL STIFFNESS}

Interleukins (ILs) are a group of cytokines produced by cells of the immune system and have a pro-inflammatory effect. They trigger the acute phase reaction by continued recruitment and activation of leukocytes, and stimulate proliferation of fibroblasts (28). An increased sympathetic tone is associated with higher oxygen consumption and enhanced production of pro-inflammatory cytokines $(19,76)$. IL-6, IL-1, and TNF- $\alpha$ impair the subendothelial release of NO and increase endothelin-1 release by ECs in a dose-dependent fashion and are thus contributing to the regulation of the vascular tone $(19,77)$. Endothelin-1 is both a potent vasoconstrictor and mitogen for smooth muscle cells and fibroblasts and IL- 6 and IL-1 were found to be the most potent and least effective stimulators of endothelin-1-release, respectively (77). Conflicting results have been obtained on the relationship IL-6-endothelial function by Cotie et al., who found that circulating IL- 6 does not mediate endothelial dysfunction, considering that no relationship was observed between IL-6 levels and flow-mediated dilatation (FMD). The authors hypothesized that until there is an overt systemic inflammatory signal, such as in a disease state, no relationship exists (78). Traditional cardiovascular risk factors impair FMD, and Vita et al. found no evidence that inflammation has additional effects beyond those attributable to traditional risk factors (15). Furthermore, cytokines stimulate VSMC and interstitial cell proliferation, contributing to the development of proliferative vascular disorders (77).

Women with a history of preeclamptic pregnancies have an increased risk of cardiovascular disease, but in a recent study no relationship was found between soluble tumor necrosis factor receptor type 1 and other systemic and vascular inflammatory markers increased during preeclamptic pregnancies and systemic arterial properties 6 months post-partum, although those markers were increased also at term. Even at term, no general correlation between the increase of systemic and vascular inflammatory markers and systemic arterial properties could be established (79). Metabolic syndrome, comprising abdominal obesity, insulin resistance, dyslipidemia, and hypertension, is accompanied by abnormal regulation of cytokines and chemokines, which further underlines the importance of inflammation in the mentioned syndrome $(80,81)$. Higher plasma levels of IL- 6 could be linked to the development of arterial stiffness and microvascular dysfunction (82).

Systemic inflammatory diseases are associated with an increased cardiovascular morbidity and mortality due to endothelial dysfunction and accelerated atherosclerosis (27). Arterial stiffness increases in accelerated atherosclerosis due to inflammation (27). An inflammatory-metabolic background is linked with increased arterial stiffness in patients with seronegative spondyloarthritis (SpA), as a positive correlation between PWV, augmentation indices, and ILs are reported in a single study with 108 subjects (53 patients and 55 controls) (83).

IL-18 has been previously associated with the formation, growth, progression, and vulnerability of the atherosclerotic plaque and was identified as an independent predictor of 
coronary events (84). Although elevated IL-12 and IL-18 levels were not associated with arterial stiffness in patients with chronic kidney disease (85), IL-18 was significantly associated with arterial stiffness in patients with metabolic syndrome (86). It is hypothesized that inflammation and arterial stiffness act together in the pathogenesis and complications of metabolic syndrome and type 2 diabetes (86). The lack of association between IL-12 and IL-18 in several studies might be explained by the different effects of inflammation on large and small vessels (85).

Associations between inflammatory gene polymorphism and cardio-ankle vascular index were found only for the cluster of differentiation 14 (CD14) polymorphism among men aged 34-49 years in a study examining polymorphisms in several inflammatory genes (87). CD14 acts as a trigger in the production of cytokines (87). Targeted deletion of genes related to costimulatory factors and pro-inflammatory cytokines results in less atherosclerosis in mouse models, while interference with regulatory immunity accelerates it (30). Among other observed effects that might be beneficial in treatment and prevention of arterial stiffness, vitamin $\mathrm{K}$ was also shown in rat studies to suppress inflammation by decreasing expression of genes for cytokines that are associated with arterial stiffness $(8,88)$.

In summary, ILs and other cytokines have been associated with arterial stiffness in several disorders, such as metabolic syndrome, SpA, and preeclampsia (Table 3) (79, 82, 83).

\section{CRP, HIGH-SENSITIVITY C-REACTIVE PROTEIN (hSCRP), AND ARTERIAL STIFFNESS}

C-reactive protein is an acute phase reactant that predicts cardiovascular events in healthy subjects and in patients with preexisting cardiovascular disorders $(89,90)$. CRP is used as a marker of chronic low-grade inflammation as it is considered as a mediator of atherothrombotic disease $(43,91,92)$ and is the only circulating biomarker related to vascular wall biology (10). CRP was correlated with FMD in some studies $(93,94)$, but no correlation was found for CRP with coronary endothelial dysfunction in patients with familial hypercholesterolemia $(95,96)$.
The level of CRP has been associated with indices of arterial function in several populations $(7,17,21,80,97-100)$. However, data regarding a possible direct etiological role of CRP in arterial dysfunction and atherosclerosis are contradictory, and there are also studies reporting no significant relationship between PWV and hsCRP $(17,101)$. Tomiyama et al. reported that the association between CRP and arterial stiffness was not retained after adjusting for other cardiovascular risk factors (101).

A significant correlation was reported between aortic flow propagation velocity (AVP), which is a parameter of reduced arterial stiffness, assessed by transthoracic echocardiography, and high CRP levels, which is indicating a link between aortic stiffness and inflammation (7). Several other cross-sectional studies demonstrated the link between metabolic syndrome, arterial stiffness, and inflammation (97). Increased CRP levels were associated with elevated PWV in patients after renal transplant, and overall CRP was suggested to be a useful marker to anticipate graft survival and cardiovascular morbidity in renal transplant recipients (102).

Rheumatoid arthritis is a chronic, systemic, inflammatory disease, associated with an increased cardiovascular mortality (21). PWV correlated independently with log-transformed CRP in patients with RA, and immunomodulatory therapy with anti-TNF- $\alpha$ therapy reduced aortic stiffness to levels comparable to those of the healthy control group. This suggests that aortic stiffness may be reversible (21). PWV correlated with current CRP, but not with disease duration, historical inflammation or extent of radiological changes (21). Traditional assays for CRP did not have adequate sensitivity to long term predict vascular disorders, and hsCRP could represent a better predictor. hsCRP was associated with arterial stiffness in several studies $(10,18$, $103,104)$, but other researchers could not find an association, independent of conventional risk factors (101). Most studies used single measurements of hsCRP instead of a mean of multiple measurements, but a single assessment seems to be adequate if values of less than $10 \mathrm{mg} / \mathrm{l}$ are observed $(43,91,92)$. hsCRP levels were correlated with traditional cardiovascular risk factors, such as hypertension, dyslipidemia, overweight, and obesity, but also with other inflammatory markers, including WBC, IL-6, and fibrinogen level (10).

TABLE 3 | Cytokines and arterial stiffness.

\begin{tabular}{|c|c|c|}
\hline Study population & Findings & Reference \\
\hline $\begin{array}{l}34 \text { women with preeclampsia and } 61 \\
\text { women with normal pregnancies }\end{array}$ & $\begin{array}{l}\text { Despite increased circulating levels of systemic and vascular inflammatory markers, such as soluble } \\
\text { tumor necrosis factor receptor type } 1 \text {, monocyte chemoattractant peptide } 1 \text { pentraxin } 3 \text {, and soluble } \\
\text { vascular adhesion molecule- } 1 \text { in preeclamptic pregnancies, they are not associated with proximal } \\
\text { aortic stiffness and effective arterial elastance }\end{array}$ & Estensen et al. (79) \\
\hline $\begin{array}{l}53 \text { patients with spondyloarthritis } \\
\text { (SpA) and } 55 \text { control subjects }\end{array}$ & $\begin{array}{l}\text { Higher mean pulse wave velocity (PWV) and augmentation indices were obtained in patients with } \\
\text { seronegative SpA compared to controls. Mean plasma levels of interleukin- } 6 \text { (IL-6), IL-1 } \beta \text {, and TNF } \alpha \\
\text { were higher in subjects with elevated PWV. Multivariate analysis revealed a significant association } \\
\text { elevated PWV and plasma levels of IL-6, IL-1 } \beta \text {, and tumor necrosis factor- } \alpha\end{array}$ & Tuttolomondo et al. (83) \\
\hline $\begin{array}{l}69 \text { healthy volunteers, } 70 \text { chronic } \\
\text { kidney disease (CKD) patients stage } \\
3-4,85 \text { CKD stage } 5\end{array}$ & $\begin{array}{l}\text { IL-12 and IL-18 were found to be elevated during the earlier stages of CKD but could NOT be } \\
\text { associated with arterial stiffness }\end{array}$ & Yong et al. (85) \\
\hline
\end{tabular}


Vascular hsCRP production is stimulated by cytokines (IL-6 and IL-1) and has modulatory functions by inhibiting endothelial NO synthase and inducing the expression of adhesion molecules in ECs. hsCRP has also a major role in increasing cytokines expression and generation of reactive oxygen species by monocytes and neutrophils, promoting vasoconstriction, VSMC migration and proliferation, activation of platelets, and vascular stiffness $(18,43,104)$. Increased hsCRP may be also a consequence of arterial stiffness because increased arterial stiffness is associated with higher flow reversals during diastole, which can increase the expression of adhesion molecules (43).

C-reactive protein and hsCRP were associated with arterial stiffness in patients with metabolic syndrome, renal transplant, diabetes mellitus, and RA (Table 4) (7, 21, 102, 104). Many interventions able to reduce cardiovascular risk have been associated with lower hsCRP values, such as weight loss, diet, exercise, smoking cessation, use of lipid-lowering drugs (statins, niacin, fibrates, gemfibrozil), aspirin, and thiazolidinediones (92).

\section{CELL ADHESION MOLECULES AND ARTERIAL STIFFNESS}

Soluble cell adhesion molecules include intercellular adhesion molecule-1 (ICAM-1), vascular cell adhesion molecule-1 (VCAM-1), the platelet (P-selectin), and endothelial selectin (E-selectin) (34). Adhesion molecules are glycoproteins involved in tissue integrity, mediation of cellular communication and interactions, and extracellular matrix contact (34). They are increased in endothelial dysfunction, vascular remodeling, and obesity. They are furthermore considered as biomarkers and mediators of cardiovascular disorders in several cardiovascular disorders, including hypertension, stroke, and coronary heart disease (34, $105,106)$. They accelerate atherosclerosis by enabling attachment of circulating leukocytes to ECs (105). E-selectin and P-selectin mediate transient rolling of leukocytes along the endothelium and ICAM-1 and VCAM-1 mediate stronger attachment of leukocytes to the endothelium (106). Adhesion molecules can not only be detected on the endothelial surface but also as soluble adhesion molecules in the circulation, where they are reported as useful biomarkers to predict future fatal cardiovascular events in patients with angiographically documented CAD (107).

Selectins are C-type lectins, including L-selectin expressed on leukocytes, E-selectin expressed by cytokine-activated ECs and P-selectin which is expressed by platelets and ECs (108). E-selectin is produced exclusively by ECs and is therefore considered a superior marker of endothelial dysfunction compared to the other cell adhesion molecules, while ICAM-1 and VCAM-1 are expressed on both ECs and leukocytes (106). ICAM-1 is also expressed in hematopoietic cells and fibroblasts and was suggested to be used as a marker of low-grade inflammation (109). VCAM-1 may be a marker of plaque activity (109), but elevated VCAM-1 levels could have a protective effect from cardiovascular events in the general population (106). While Kilic et al. found no correlation between VCAM-1 and ICAM-1 and arterial stiffness, de Faria et al. reported higher VCAM-1 values in patients with increased arterial stiffness $(34,109)$. Further studies assessing VCAM-1 and arterial stiffness could clarify the relationship between VCAM-1 and arterial stiffness.

Kals et al. enrolled 39 patients with peripheral arterial disease and 34 controls and found a significantly reduced endothelial function index, an increased augmentation index (AI), estimated PWV, ICAM-1, hsCRP, myeloperoxidase, and urinary 8-isoprostaglandin F2a (110). They found an inverse, significant

TABLE 4 | C-reactive protein (CRP), high-sensitivity C-reactive protein (hSCRP), and arterial stiffness.

\begin{tabular}{|c|c|c|}
\hline Study population & Findings & Reference \\
\hline $\begin{array}{l}100 \text { patients with metabolic } \\
\text { syndrome, } 14 \text { controls }\end{array}$ & $\begin{array}{l}\text { There was a significant correlation between aortic flow propagation velocity (AVP), FMD (flow- } \\
\text { mediated dilatation), and high CRP, indicating a possible link between aortic stiffness, endothelial } \\
\text { dysfunction, and inflammation }\end{array}$ & Adel et al. (7) \\
\hline 150 renal transplant recipients & $\begin{array}{l}\text { High (> } 20 \text { mg/L) post-transplant CRP levels predicted pulse wave velocity (PWV) and cardiovascular } \\
\text { morbidity in a two-year time period after renal transplantation }\end{array}$ & Gurlek Demirci et al. (102) \\
\hline $\begin{array}{l}40 \text { patients with type } 2 \text { diabetes } \\
\text { mellitus }\end{array}$ & $\begin{array}{l}\text { hsCRP showed a moderate positive correlation with arterial stiffness in patients with type } 2 \text { diabetes } \\
\text { mellitus }\end{array}$ & Nurizal et al. (104) \\
\hline 825 men (mean age: 74 years) & Arterial stiffness was found to correlate positively with circulating levels of CRP & McEniery et al. (100) \\
\hline 362 middle-aged and elderly men & $\begin{array}{l}\text { Low-grade inflammation was shown to be independently related to increase of aortic artery stiffness } \\
\text { over and above traditional risk factors and atherosclerosis }\end{array}$ & Nakhai-Pour et al. (43) \\
\hline $\begin{array}{l}77 \text { patients with rheumatoid arthritis } \\
\text { (RA) and } 142 \text { healthy individuals }\end{array}$ & $\begin{array}{l}\text { Median aortic PWV was significantly higher in RA patients than in control subjects and correlated } \\
\text { independently with age, mean arterial pressure, and CRP }\end{array}$ & Mäki-Petäjä et al. (21) \\
\hline $\begin{array}{l}214 \text { asymptomatic subjects with a } \\
\text { mean age of } 59 \text { years }\end{array}$ & CRP was related to measures of arterial wave reflection and stiffness in asymptomatic subjects & Kullo et al. (99) \\
\hline 866 participants above 55 years & Levels of CRP were linearly associated with PWV & Mattace-Raso et al. (98) \\
\hline $\begin{array}{l}\text { 2,668 Japanese men }(43 \pm 10 \text { years } \\
\text { old) }\end{array}$ & $\begin{array}{l}\text { PWV showed a significant correlation with the logarithm of hsCRP, but multiple linear regression } \\
\text { analyses demonstrated that the logarithm of hsCRP was not significantly related to PWV, independent } \\
\text { from conventional risk factors }\end{array}$ & Tomiyama et al. (101) \\
\hline $\begin{array}{l}158 \text { apparently healthy subjects } \\
\text { (age range } 40-65 \text { years) }\end{array}$ & $\begin{array}{l}\text { Plasma levels of hsCRP were positively correlated with Alx, central pulse pressure and central systolic } \\
\text { blood pressure }\end{array}$ & Kampus et al. (103) \\
\hline
\end{tabular}


association between endothelial function index and ICAM-1 only in the controls, and significant correlations between PWV and AI, respectively, and urinary 8 -iso-prostaglandin F2a in patients (110). The study demonstrated the importance of the degree of inflammation for endothelial vasomotor capacity in the subclinical condition and of oxidative stress for arterial stiffness (110).

Vascular adhesion protein-1 (VAP-1) is associated with cell membranes (in ECs, smooth muscle cells, and adipocytes) but also found as soluble VAP-1 in plasma. It serves both the function as an adhesion molecule and an amine oxidase producing aldehyde and hydrogen peroxide. It is involved in vascular injury due to its semicarbazide-sensitive amine oxidase (SSAO) activity because of releasing of formaldehyde and methylglyoxal from the breakdown of primary amines, which is responsible for direct cytotoxic damage to ECs $(111,112)$. VAP-1 was associated with arterial stiffness in subjects over 60 years after adjusting for PWVrelated confounders (112). Inflammation is the main link between VAP-1 and arterial stiffness, impairing the balance between production and degradation of collagen and elastin fibers, resulting in overproduction of abnormal collagen and reducing quantities of normal elastin (6). As an adhesion molecule, VAP-1 is involved in the rolling, adhesion, and transmigration of lymphocytes, granulocytes, and monocytes from the blood into the vessel wall, and the oxidase activity of VAP-1 may have signaling effects and induce expression of E- and P-selectins and ICAM-1 in ECs $(113,114)$. VAP-1 is also involved in endothelial dysfunction and synthesis of advanced glycation end products that are well known to contribute to an increase in arterial stiffness. Furthermore, SSAO activity was associated with an abnormal elastin structure and production of reactive oxygen species (112).

In systemic lupus erythematosus, antiphospholipid antibodies bind to receptors on the endothelium to upregulate adhesion molecules such as E-selectin, ICAM-1, and VCAM-1, but the presence of the antibodies was not associated with arterial stiffness (27).

In summary, adhesion molecules were associated with arterial stiffness in patients with a peripheral arterial disease, resistant hypertension, and subjects over 60 years (Table 5) $(34,110)$.

\section{ORAL INFECTIONS AND ARTERIAL STIFFNESS}

The association between oral inflammation and the risk of major cardiovascular events, such as myocardial infarction and stroke, was described two decades ago $(115,116)$. Bacteria and their products from the dental plaque and crevicular fluid are involved in local destruction of gingiva and bone and they are also released to the bloodstream (117).

Periodontitis is associated with endothelial dysfunction due to periodontal pathogens, atherosclerosis, an increased risk of myocardial infarction, stroke, and peripheral arterial disease $(118,119)$. A $19 \%$ increase in the risk of cardiovascular disease was reported, and the risk increases in elderly patients $(119,120)$. Periodontitis and cardiovascular disorders share several risk factors, such as age, heredity, smoking, diabetes mellitus, hypertension, estrogen deficiency in women, a low socioeconomic status, and stress $(117,119)$.

Microbial pathogens associated with periodontal disease, predominantly Gram-negative bacteria, cause high levels of bacteremia after routine dental procedures and every day activities, including tooth brushing (121) and a chronic, progressive, destructive, and unresolved inflammation $(122,123)$. Periodontal pathogens and their noxious products gain access to the periodontal tissues and are released into the systemic circulation through the ulcerated sulcular epithelium of the gingiva, and they are a source of inflammatory mediators, which can cause insulin resistance, systemic inflammation, and explain, probably, the perio-systemic link $(119,124,125)$. Porphyromonas gingivalis and Treponema denticola, bacteria causing periodontal disease, have been found in the atherosclerotic plaque (117). The levels of biomarkers such as hsCRP, TNF- $\alpha$, and interleukin- 6 and -1 were increased in patients with periodontitis. The autoimmune mechanism is involved in both periodontal disease and RA, which explains the significant association of both disorders associated with an increased cardiovascular risk (119). High periodontal bacteria antibodies titers were associated with atherosclerosis, regardless of smoking status $(118,126)$, and improvement in clinical and microbial periodontal status was associated with a decreased rate of carotid artery IMT progression (127). Probably, the atherosclerotic process is initiated or accelerated by the inflammatory periodontal reaction (128). It is also possible that a common pathway leads independently to both periodontal disease and atherosclerosis (117).

Several studies reported an increased arterial stiffness in patients with periodontitis compared to controls, suggesting that patients with periodontitis suffer from a subclinical vascular dysfunction (Table 6) (129-134). Future research should point out the relationship between active treatment of periodontitis

TABLE 5 | Adhesion molecules and arterial stiffness.

\begin{tabular}{|c|c|c|}
\hline Study population & Findings & Reference \\
\hline $\begin{array}{l}110 \text { patients with resistant hypertension and } \\
112 \text { mild to moderate hypertensive patients }\end{array}$ & $\begin{array}{l}\text { sP-selectin and SVCAM-1 were elevated in the presence of arterial stiffness and cardiac } \\
\text { hypertrophy }\end{array}$ & de Faria et al. (34) \\
\hline 63 participants referred for echocardiography & $\begin{array}{l}\text { No correlation was demonstrated between indices of aortic stiffness and vascular cell adhesion } \\
\text { molecule-1 and intercellular adhesion molecule- } 1 \text { levels }\end{array}$ & Kilic et al. (109) \\
\hline $\begin{array}{l}568 \text { Han Chinese healthy persons with an age } 30 \\
\text { or older }\end{array}$ & $\begin{array}{l}\text { Plasma vascular adhesion protein-1 (VAP-1) was associated with arterial stiffness in older } \\
\text { individuals. VAP-1 may be important for vascular aging }\end{array}$ & Chen et al. (112) \\
\hline $\begin{array}{l}39 \text { patients with peripheral arterial disease and } 34 \\
\text { controls }\end{array}$ & $\begin{array}{l}\text { There was an inverse association between endothelial function index and intercellular adhesion } \\
\text { molecule- } 1 \text { in the controls, but not in the patients }\end{array}$ & Kals et al. (110) \\
\hline
\end{tabular}


TABLE 6 | Periodontitis and arterial stiffness.

\begin{tabular}{|c|c|c|}
\hline Study population & Findings & Reference \\
\hline $\begin{array}{l}80 \text { volunteers and } 33 \text { pairs of } \\
\text { periodontitis patients, matched by age } \\
\text { and gender }\end{array}$ & $\begin{array}{l}\text { An association between arterial stiffness and periodontitis was suggested by a lower degree of } \\
\text { uniformity in the transmission of the pulse wave through the carotid arteries }\end{array}$ & Sanz-Miralles et al. (136) \\
\hline $\begin{array}{l}57 \text { periodontitis patients and } 48 \text { healthy } \\
\text { controls }\end{array}$ & $\begin{array}{l}\text { PWV was measured and followed up } 6 \text { months after periodontal therapy. PWV was significantly } \\
\text { higher in periodontitis patients compared to the reference group even after adjusting for } \\
\text { cardiovascular risk factors. Periodontal treatment did not lower significantly PWV }\end{array}$ & Houcken et al. (134) \\
\hline $\begin{array}{l}92 \text { patients with periodontitis and } 66 \\
\text { matched healthy controls }\end{array}$ & $\begin{array}{l}\text { Significantly higher PWV, aortic augmentation index, and central blood pressure and lower pulse } \\
\text { pressure amplification values were found in subjects with severe or aggressive periodontitis }\end{array}$ & Jockel-Schneider et al. (132) \\
\hline 273 indigenous Australian adults & Arterial stiffness significantly increased with increasing extent of periodontal pocketing & Kapellas et al. (131) \\
\hline $\begin{array}{l}532 \text { gingivitis and } 282 \text { periodontitis } \\
\text { cases (Asian Indians) }\end{array}$ & $\begin{array}{l}\text { PWV and arterial stiffness index were elevated in periodontitis compared to gingivitis cases and } \\
\text { in those with diabetes and hypertension }\end{array}$ & Shanker et al. (130) \\
\hline $\begin{array}{l}\text { 1,053 Japanese subjects with } 10 \text { teeth } \\
\text { or more }\end{array}$ & $\begin{array}{l}\text { A linear, dose-dependent relationship was found between periodontal pocket depth and arterial } \\
\text { stiffness }\end{array}$ & Hayashida et al. (129) \\
\hline $\begin{array}{l}26 \text { patients with refractory hypertension } \\
\text { and generalized chronic periodontitis }\end{array}$ & $\begin{array}{l}\text { Periodontal therapy significantly reduced the level of CRP, IL-6, fibrinogen, blood pressure, left } \\
\text { ventricular mass and arterial stiffness, lowering cardiovascular risk }\end{array}$ & Vidal et al. (135) \\
\hline $\begin{array}{l}16 \text { periodontally healthy, } 87 \text { gingivitis, } \\
\text { and } 18 \text { periodontitis patients with type } 2 \\
\text { diabetes mellitus }\end{array}$ & $\begin{array}{l}\text { Periodontal inflammation in patients with type } 2 \text { diabetes mellitus is associated with increased } \\
\text { intima-media thickness and blood pressure, but not with greater arterial stiffness }\end{array}$ & Franek et al. (117) \\
\hline
\end{tabular}

PWV, pulse wave velocity; CRP, C-reactive proteins; IL-6, interleukin-6.

and cardiovascular benefits, because the results of the interventional studies are contradictory, especially in obese patients $(117,133,135)$.

Concluding, arterial stiffness is impaired in patients with periodontitis. No study reported yet a symbiotic relationship between periodontitis and arterial stiffness or any relationship between odontogenic foci and arterial stiffness, and those could be aims of future studies.

\section{MICRORNAS AND VASCULAR INFLAMMATION}

Increasing evidence indicate that miRNAs, which are small non-coding RNAs, able to regulate gene expression and to prevent or reduce protein synthesis, have distinct profiles and play crucial roles in various physiological and pathological processes, including vascular aging and inflammation (137-140). An imbalance in the normal miRNA profile can be identified long before the onset of a disease $(139,141)$. MicroRNAs, such as miR-126 and miR-10a, can control vascular inflammation due to leukocyte activation and infiltration through the vascular wall (142). MicroRNA-663 specifically mediated shear stress-induced monocyte adhesion to ECs (143). Let-7g reduced, besides ECs senescence, also EC inflammation and monocyte adhesion (144). MicroRNA-181b shift macrophage polarization toward M2 anti-inflammatory phenotype, reducing macrophage accumulation and enabling tissue repair (145). Another microRNA, miR-92a, the "atheromiR candidate," upregulated by oxLDL, is a pro-inflammatory regulator in ECs by modulating inflammatory cytokines and chemokines, enabling monocyte adhesion (146). MicroRNA-92a controls also neovascularization after ischemic injury (140). MicroRNAs can also regulate adhesion molecules expression, especially miR-21 and miR-126. MicroRNA-21, highly expressed in the cardiovascular system, is the most abundant microRNA in monocytes/macrophages, related to a pro-inflammatory phenotype, control of the flow-induced inflammatory response, mediating the balance of pro- and anti-inflammatory responses, expression of adhesion molecules, polarization of macrophages and macrophage apoptosis (147). Zhou et al. demonstrated that miR-21 acts as an epigenetic mediator of the pro-inflammatory phenotype of the vascular ECs exposed to oscillatory shear stress, inhibiting expression of peroxisome proliferators-activated receptor-alpha and upregulating activator protein-1 and expression of adhesion molecules (138). A study including 95 hypertensive patients, evaluated at baseline and after 1 year of effective antihypertensive therapy, showed independent correlations between levels of miR-21 and changes of PWV, independent of blood pressure values, highlighting the significance of miR-21 in vascular remodeling (139). MicroRNA-21 enables also fibrosis in the vascular wall related to AII, promoting proliferation of interstitial fibroblasts and deposition of the extracellular matrix (139). It is also involved in regulation of VSMC phenotype and suppression of endothelial progenitor cell proliferation (139). Harris et al. showed that miR126 inhibits VCAM-1 expression, limiting leukocyte adhesion to the vascular endothelium (137). However, miR-126 is also involved in angiogenic signaling (141). MicroRNA-30 reduces basal and TNF- $\alpha$-induced expression of adhesion molecules: VCAM-1, ICAM-1, and E-selectin, impairing the expression of angiopoietin 2 and contributing to the atheroprotective effects of shear stress (148). Deng et al. enrolled 406 Chinese participants in a study and measured miR-1185, adhesion molecules levels (VCAM-1 and E-selectin), and arterial stiffness, reporting independent correlations of microRNA with PWV and adhesion molecules, respectively (149). 
It is too early to consider microRNAs as diagnostic and prognostic biomarkers or therapeutic target for arterial stiffness, because there are very few studies linking vascular function and non-coding RNAs. However, miRNAs could be useful as markers of vascular remodeling and plaque instability in future studies.

\section{CYCLOOXYGENASE-2 (COX-2), PROSTAGLANDIN SIGNALING, AND ARTERIAL STIFFNESS}

During inflammation, phospholipase brakes down phospholipids of the WBC membrane into arachidonic acid, which enables synthesis of prostaglandins through the cyclooxigenase pathway, involving cyclooxygenase 1 and 2 . The prostaglandins formed by the COX-2 pathway perpetuate inflammation and amplify the effects of other inflammatory mediators, due to its upregulation in monocyte-derived macrophages from the atherosclerotic lesions (150, 151). Microsomal prostaglandin E2 synthase-1 (mPGES-1) catalyzes prostaglandin E2 generation from prostaglandin $\mathrm{H} 2$, is primary coupled to COX-2, is strongly upregulated in inflamed tissues, and represents a key enzyme in atherosclerosis and stroke $(152,153)$. In atherosclerosis of the carotid arteries, both COX-2 and $\mathrm{mPGES}-1$ are upregulated in the vulnerable area of the plaque and may favor plaque instability (152).

The relationship between COX-2 and vascular remodeling was described in the pulmonary circulation. Pulmonary arterial stiffness occurs early in experimental pulmonary hypertension and is an independent risk factor for mortality in pulmonary hypertension (154). COX-2 is upregulated in pulmonary artery smooth muscle cells during hypoxia, associated with upregulation of the endothelin receptor (155) and intravascular macrophage accumulation (156). The transcriptional regulator Yes-associated protein activity is increased in pulmonary hypertension in pulmonary artery smooth muscle cells and is necessary for development of stiffness-dependent remodeling phenotypes (154). However, selective COX-2 inhibition impairs the balance of vascular mediators, enables vascular hyperplasia, remodeling of the systemic vessels, platelet deposition, intravascular thrombosis, and is associated with several cardiovascular events (155).

Cyclooxygenase-2 derived prostaglandin E2, acting on EP1 receptors, is responsible for increased arterial stiffness, increased vasoconstrictor responses, extracellular matrix deposition, endothelial dysfunction, and vascular inflammation (157). AII induces expression of COX-2 and prostanoids in several vessels, and high levels of AII are expressed in vessels of hypertensive patients (157).

On the other hand, Vlachopoulos et al. demonstrated that, especially, COX-1, and also COX-2 mediate the unfavorable effects of smoking on arterial stiffness (158). Endothelial function was not improved by indomethacin or rofecoxib in patients with RA (159), and meanwhile, rofecoxib was withdrawn from the market considering the increased risk of atherothrombotic events associated with this class of drugs (150).

Despite the mechanisms linking COX-2, inflammation, and arterial stiffness, chronic COX-2 inhibition is not an effective destiffening solution, because of its prothrombotic and hypertensive undesirable effects. There is urgent need for the discovery of new effective and cardiovascular safe anti-inflammatory drugs, and mPGES-1 inhibitors may be the solution.

\section{STUDY LIMITATIONS}

Most of the studies were cross-sectional, often with only a relatively small number of participants, and sometimes with just one measurement of inflammatory markers, all of which is unfavorable for the significance of results and their interpretation. The cross-sectional design of most studies cannot establish causality, it can only establish an association (102). Relatively small numbers of study participants, which are often a specific subgroup of patients with certain morbidities does not allow to extend conclusions to the general population; therefore, the results of many studies presented here need confirmation in larger studies. Other limitations arise from an election bias due to exclusion of patients with active infections, and not considering PP amplification and the fact that arterial stiffness is not a uniform condition in all arteries $(19,98)$. Also, the possibility of undetected disease in study participants limits the significance of studies (57). Usually, patients with established and not early disease were studied and it is not clear if changes in arterial properties precede increase of inflammatory markers and if there is an etiological link between inflammatory markers and cardiovascular complications. It is also still not clear if old or cumulative inflammation or just acute or subacute inflammation correlate with arterial stiffness (21).

Several confounding factors may influence the level of inflammatory markers and not all of them are known currently. The level of soluble adhesion molecules is, for example, at least influenced by age, smoking status, diabetes mellitus, other inflammatory conditions, exercise, and changes in blood pressure (109). The variance of CRP due to LDL cholesterol was less than 3-5\%, and values of CRP are stable over long periods, with almost no circadian variation and are not influenced by food intake (92). Major infections, trauma, and hospitalization may increase CRP 100 -fold or more, and values exceeding $10 \mathrm{mg} / \mathrm{l}$ should be ignored and the test should be repeated (92).

Also, the methodologies of assessing arterial stiffness are limiting the significance of the obtained results. For example, PWV measurements have the immanent problem that it remains difficult to accurately record the femoral pressure wave in participants with peripheral artery disease, and also obesity affects the absolute value of PWV by overestimating the distance and thus yielding artificial values (160). Also, measurements of blood pressure values present a possible source of limiting significance, since blood pressure values are often derived via the brachial PP using a sphygmomanometer and are then converted into central PP by a transfer function. However, since vascular dimensions depend on body size and vascular properties vary with arterial pressure, age, or treatment, the premise that the characteristics of the vascular system between the two measuring sites are the same in all individuals and under all conditions is therefore not true (161). More sophisticated inflammatory markers, such as adhesion molecules and ILs, are inappropriate for routine clinical use $(91,92)$. 


\section{CONCLUSION}

There is ample evidence of a crosstalk between arterial stiffness and systemic inflammation, and inflammation plays an important role in the development of arterial stiffness. Inflammatory markers may be useful additional tools in the assessment of the cardiovascular risk, atherosclerotic plaque remodeling, and preclinical atherosclerotic changes in clinical practice and may be used to develop risk scores for possible future cardiovascular events. This might help to close the currently existing gap between predicted cardiovascular events and their real prevalence. Most of the inflammatory markers are inexpensive and easily measurable, widely available, standardized and may be included in the annual examination of patients at risk, considering that inflammation causes a reversible increase of arterial stiffness.

Several studies revealed significant associations between arterial stiffness and inflammatory markers, such as WBC, NLR, adhesion molecules, fibrinogen, CRP, hsCRP, cytokines, microRNAs, and COX-2 in patients with metabolic syndrome, diabetes mellitus, coronary heart disease, systemic and pulmonary hypertension, peripheral arterial disease, malignant and inflammatory rheumatic disorders, polycystic kidney disease, renal transplant, FMF, in women with preeclampsia or after menopause, and in patients with severe periodontitis. Further studies are needed, in several other disorders and healthy subjects, to confirm the

\section{REFERENCES}

1. Shirwany NA, Zou M. Arterial stiffness: a brief review. Acta Pharmacol Sin (2010) 31:1267-76. doi:10.1038/aps.2010.123

2. Van Bortel LM, Struijker-Boudier H, Safar ME. Pulse pressure, arterial stiffness, and drug treatment of hypertension. Hypertension (2001) 38(4): 914-21. doi:10.1161/hy1001.095773

3. Avolio A, Butlin M, Liu YY, Viegas K, Avadhanam B, Lindesay G. Regulation of arterial stiffness: cellular, molecular and neurogenic mechanisms. Artery Res (2011) 5:122-7. doi:10.1016/j.artres.2011.10.002

4. Townsend RR. Arterial stiffness and chronic kidney disease: lessons from the chronic renal insufficiency cohort study. Curr Opin Nephrol Hypertens (2015) 24(1):47-53. doi:10.1097/MNH.0000000000000086

5. Hughes TM, Craft S, Lopez OL. Review of 'the potential role of arterial stiffness in the pathogenesis of Alzheimer's disease'. Neurodegener Dis Manag (2015) 5(2):121-35. doi:10.2217/nmt.14.53

6. Zieman SJ, Melenovsky V, Kass DA. Mechanisms, pathophysiology, and therapy of arterial stiffness. Arterioscler Thromb Vasc Biol (2005) 25:932-43. doi:10.1161/01.ATV.0000160548.78317.29

7. Adel M, ELSheikh A, Sameer S, Haseeb W, ELSheikh E, Kheder L. Arterial stiffness in metabolic syndrome. J Saudi Heart Assoc (2016) 28:249-56. doi:10.1016/j.jsha.2015.12.005

8. Mozos I, Stoian D, Luca CT. Crosstalk between vitamins A, B12, D, K, C and E status and arterial stiffness. Dis Markers (2017) 2017:8784971. doi: $10.1155 / 2017 / 8784971$

9. Erbel R, Aboyans V, Boileau C, Bartolomeo RD, Eggebrecht H, Evangelista A, et al. 2014 ESC guidelines on the diagnosis and treatment of aortic diseases. Document covering acute and chronic aortic diseases of the thoracic and abdominal aorta of the adult. Eur Heart J (2014) 35:2873-926. doi:10.1093/ eurheartj/ehu281

10. Vlachopoulos C, Xaplanteris P, Aboyans V, Brodmann M, Cifkova R, Cosentino F, et al. The role of vascular biomarkers for primary and secondary prevention. A position paper from the European Society of Cardiology Working Group on peripheral circulation: endorsed by the Association for Research into Arterial Structure and Physiology (ARTERY) Society. Atherosclerosis (2015) 241:507-32. doi:10.1016/j.atherosclerosis.2015.05.007 reversible association linking arterial stiffness and inflammatory markers and its predictive value for cardiovascular events.

Combined assessment of arterial stiffness and inflammatory markers may improve non-invasive assessment of cardiovascular risk in several disorders, enabling selection of high-risk patients for prophylactic treatment or more regular medical examination. Development of future destiffening therapies may target proinflammatory mechanisms, including miRNAs, enabling stabilization of the atherosclerotic plaque, control of cardiovascular risk factors, and inflamm-aging.

\section{AUTHOR CONTRIBUTIONS}

IM has written the first draft of the manuscript. CM, JH, CG, DS, CL, and AA revised and improved the first draft. All authors have seen and agreed on the finally submitted version of the manuscript.

\section{FUNDING}

The authors acknowledge the support by the Polish KNOW (Leading National Research Centre) Scientific Consortium "Healthy Animal-Safe Food," decision of Ministry of Science and Higher Education No. 05-1/KNOW2/2015.

11. Cecelja M, Chowienczyk P. Arterial stiffening: causes and consequences. Artery Res (2013) 7:22-7. doi:10.1016/j.artres.2012.09.001

12. Shibata T, Tsutsumi J, Hasegawa J, Sato N, Murashima E, Mori C, et al. Effects of add-on therapy consisting of a selective mineralocorticoid receptor blocker on arterial stiffness in patients with uncontrolled hypertension. Intern Med (2015) 54:1583-9. doi:10.2169/internalmedicine. 54.3427

13. Lacolley P, Challande P, Regnault V, Lakattac EG, Wang M. Cellular and molecular determinants of arterial aging. In: Nilsson P, Olsen M, Laurent S, editors. Early Vascular Aging. Academic Press, Elsevier (2015). p. 7-13.

14. Smulyan H, Mookherje S, Safar ME. Two faces of hypertension: role of aortic stiffness. J Am Soc Hypertens (2016) 10(2):175-83. doi:10.1016/j. jash.2015.11.012

15. Vita JA, Keaney JF Jr, Larson MG, Keyes MJ, Massaro JM, Lipinska I, et al. Brachial artery vasodilator function and systemic inflammation in the Framingham Offspring Study. Circulation (2004) 110(23):3604-9. doi:10.1161/01.CIR.0000148821.97162.5E

16. Hansson GK. Inflammation, atherosclerosis, and coronary artery disease. N Engl J Med (2005) 352:1685-95. doi:10.1056/NEJMra043430

17. Aznaouridis KA, Stefanadis CI. Inflammation and arterial function. Artery Res (2007) 1:32-8. doi:10.1016/j.artres.2007.03.005

18. Park S, Lakatta EG. Role of inflammation in the pathogenesis of arterial stiffness. Yonsei Med J (2012) 53(2):258-61. doi:10.3349/ ymj.2012.53.2.258

19. Ayhan H, Kasapkara HA, Aslan AN, Durmaz T, Keles T, Akcay M, et al. Relationship of neutrophil-to-lymphocyte ratio with aortic stiffness in type 1 diabetes mellitus. Can J Diabetes (2015) 39:317-21. doi:10.1016/j. jcjd.2015.01.004

20. Jain S, Khera R, Corrales-Medina VF, Townsend RR, Chirinos JA. Inflammation and arterial stiffness in humans. Atherosclerosis (2014) 237(2):381-90. doi:10.1016/j.atherosclerosis.2014.09.011

21. Mäki-Petäjä KM, Hall FC, Booth AD, Wallace SM, Yasmin, Bearcroft PW, et al. Rheumatoid arthritis is associated with increased aortic pulse-wave velocity, which is reduced by anti-tumor necrosis factor-alpha therapy. Circulation (2006) 114(11):1185-92. doi:10.1161/CIRCULATIONAHA.105 601641 
22. Sattar N, McCarey DW, Capell H, McInnes IB. Explaining how "high-grade" systemic inflammation accelerates vascular risk in rheumatoid arthritis. Circulation (2003) 108:2957-63. doi:10.1161/01.CIR.0000099844.31524.05

23. Gerli R, Schillaci G, Giordano A, Bocci EB, Bistoni O, Vaudo G, et al. CD4+ CD28- T lymphocytes contribute to early atherosclerotic damage in rheumatoid arthritis patients. Circulation (2004) 109:2744-8. doi:10.1161/01. CIR.0000131450.66017.B3

24. Loius SF, Zahradka P. Vascular smooth muscle cell motility: from migration to invasion. Exp Clin Cardiol (2010) 15(4):e75-85.

25. Libby P, Ridker PM, Maseri A. Inflammation and atherosclerosis. Circulation (2002) 105(963):1135-43. doi:10.1161/hc0902.104353

26. Drechsler M, Megens RTA, Van Zandvoort M, Weber C, Soehnlein O. Hyperlipidemia-triggered neutrophylia promotes early atherosclerosis. Circulation (2010) 122(18):1837-45. doi:10.1161/CIRCULATIONAHA. 110.961714

27. Yildiz M. Arterial distensibility in chronic inflammatory rheumatic disorders. Open Cardiovasc Med J (2010) 4:83-8. doi:10.2174/1874192401004020083

28. Jones DP, True HD, Patel J. Leukocyte trafficking in cardiovascular disease: insights from experimental models. Mediators Inflamm (2017) 2017:9746169. doi:10.1155/2017/9746169

29. McEniery CM, Qasem A, Schmitt M, Avolio AP, Cockcroft JR, Wilkinson IB. Endothelin-1 regulates arterial pulse wave velocity in vivo. J Am Coll Cardiol (2003) 42(11):1975-81. doi:10.1016/j.jacc.2003.06.016

30. Hansson GK, Hermansson A. The immune system in atherosclerosis. Nat Immunol (2011) 12:204-12. doi:10.1038/ni.2001

31. Stein S, Lohmann C, Schafer N, Hofmann J, Rohrer L, Besler C, et al. SIRT 1 decreases LOX-1 mediated foam cell formation in atherogenesis. Eur Heart $J$ (2010) 31:2301-9. doi:10.1093/eurheartj/ehq107

32. Siti HN, Kamisah Y, Kamisah J. The role of oxidative stress, antioxidants and vascular inflammation in cardiovascular disease (a review). Vascul Pharmacol (2015) 71:40-56. doi:10.1016/j.vph.2015.03.005

33. Pirillo A, Norata GD, Catapano AL. LOX-1, OxLDL, and atherosclerosis. Mediators Inflamm (2013) 2013:152786. doi:10.1155/2013/152786

34. de Faria AP, Ritter AM, Sabbatini AR, Correa NB, Brunelli V, Modolo R, et al. Deregulation of soluble adhesion molecules in resistant hypertension and its role in cardiovascular remodeling. Circ J (2016) 80(5):1196-201. doi:10.1253/circj.CJ-16-0058

35. Michaud M, Balardy L, Moulis G, Gaudin C, Peyrot C, Vellas B, et al. Proinflammatory cytokines, aging and age related diseases. J Am Med Dir Assoc (2013) 14:877-82. doi:10.1016/j.jamda.2013.05.009

36. Mc Gill HC Jr, Mc Mahan CA, Herderick EE, Malcom GT, Tracy RE, Strong JP. Origin of atherosclerosis in childhood and adolescence. Am J Clin Nutr (2000) 72(5 Suppl):1307S-15S.

37. Papaioannou TG, Karatzi K, Psaltopoulou T, Tousoulis D. Arterial ageing: major nutritional and life-style effects. Ageing Res Rev (2017) 37:162-3. doi:10.1016/j.arr.2016.10.004

38. Wang M, Jiang L, Monticone RE, Lakatta EG. Proinflammation: the key to arterial aging. Trends Endocrinol Metab (2014) 25(2):72-9. doi:10.1016/j. tem.2013.10.002

39. Accardi G, Aiello A, Gambino CM, Virruso C, Caruso C, Candore G. Mediterranean nutraceutical foods: strategy to improve vascular ageing. Mech Ageing Dev (2016) 159:63-70. doi:10.1016/j.mad.2016.02.007

40. Mozos I, Luca CT. Crosstalk between oxidative and nitrosative stress and arterial stiffness. Curr Vasc Pharmacol (2017) 15:446-56. doi:10.2174/1570 161115666170201115428

41. Galis ZS, Khatri JJ. Matrix metalloproteinases in vascular remodeling and atherogenesis: the good, the bad and the ugly. Circ Res (2002) 90:251-62. doi:10.1161/hh0302.105345

42. Wang M, Zhang J, Jiang LQ, Spinetti G, Pintus G, Monticone R, et al. Proinflammatory profile within the grossly normal aged human aortic wall. Hypertension (2007) 50:219-27. doi:10.1161/HYPERTENSIONAHA. 107.089409

43. Nakhai-Pour HR, Grobbee DE, Bots ML, Muller M, van der Schouw YT. C-reactive protein and aortic stiffness and wave reflection in middle-aged and elderly men from the community. J Hum Hypertens (2007) 21(12):949-55. doi:10.1038/sj.jhh.1002255

44. Tanindi A, Erkan AF, Alhan A, Töre HF. Arterial stiffness and central arterial wave reflection are associated with serum uric acid, total bilirubin, and neutrophil-to lymphocyte ratio in patients with coronary artery disease. Anatol J Cardiol (2015) 15(5):396-403. doi:10.5152/akd.2014.5447

45. Mäki-Petäjä KM, Wilkinson IB. Anti-inflammatory drugs and statins for arterial stiffness reduction. Curr Pharm Des (2009) 15(3):290-303. doi:10.2174/138161209787354221

46. Hussein AM, Shaaya G, Arora R, Al-Khazaali A, Al-Khafaji K, Helu HK. Therapeutic modulation of aortic stiffness. Am J Ther (2016) 23(6):e1644-53. doi:10.1097/MJT.0000000000000408

47. Mozos I, Borzak G, Caraba A, Mihaescu R. Arterial stiffness in hematologic malignancies. Onco Targets Ther (2017) 10:1381-8. doi:10.2147/OTT. S126852

48. Bhat T, Teli S, Rijal J, Bhat H, Raza M, Khoueiry G, et al. Neutrophil to lymphocyte ratio and cardiovascular diseases: a review. Expert Rev Cardiovasc Ther (2013) 11(1):55-9. doi:10.1586/erc.12.159

49. Bain BJ. Ethnic and sex differences in the total and differential white cell count and platelet count. J Clin Pathol (1996) 49:664-6. doi:10.1136/jcp.49.8.664

50. Angeli F, Angeli E, Ambrosio G, Mazotta G, Cavallini C, Reboldi G, et al. Neutrophil count and ambulatory pulse pressure as predictors of cardiovascular adverse events in postmenopausal women with hypertension. Am J Hypertens (2011) 24(5):591-8. doi:10.1038/ajh.2011.18

51. Abo T, Kawamura T. Immunomodulation by the autonomic nervous system: therapeutic approach for cancer, collagen diseases, and inflammatory bowel diseases. Ther Apher (2002) 6(5):348-57. doi:10.1046/j.1526-0968.2002. 00452.x

52. Mozos I, Mihaescu R. Crosstalk between arterial stiffness, arterial age and blood count in hematologic malignancies. Jökull (2015) 65(9):105-15.

53. Mozos I, Mihaescu R. Pulse wave velocity and central hemodynamic indices in patients with malignant solid tumors. Jökull (2015) 65(9):200-14.

54. Steinberg MH, Charm SE. Effect of high concentrations of leukocytes on whole blood viscosity. Blood (1971) 38(3):299-301.

55. Cowan AQ, Cho DJ, Rosenson RS. Importance of blood rheology in the pathophysiology of aherothrombosis. Cardiovasc Drug Ther (2012) 26(4):339-48. doi:10.1007/s10557-012-6402-4

56. Gomez-Sanchez L, Garcia-Ortiz L, Recio-Rodriguez JI, Patino-Alonso MC, Agudo-Conde C, Rigo F, et al. Leukocyte subtype counts and its association with vascular structure and function in adults with intermediate cardiovascular risk. MARK study. PLoS One (2015) 10(4):e0119963. doi:10.1371/ journal.pone. 0119963

57. Yildiz M, Masatlioglu S, Seymen P, Aytac E, Sahin B, Seymen HO. The carotid-femoral (aortic) pulse wave velocity as a marker of arterial stiffness in familial Mediterranean fever. Can J Cardiol (2006) 22(13):1127-31. doi:10.1016/S0828-282X(06)70949-7

58. Cakar M, Akhan M, Dogan T, Taskin G, Öztürk K, Cinar M, et al. Investigation of the arterial stiffness and associated factors in patients with familial Mediterranean fever. Anatol J Cardiol (2017) 17(2):132-8. doi:10.14744/ AnatolJCardiol.2016.6985

59. Alghamdi M. Familial Mediterranean fever, review of the literature. Clin Rheumatol (2017) 36(8):1707-13. doi:10.1007/s10067-017-3715-5

60. Nidorf M, Thompson PL. Effect of colchicine ( $0.5 \mathrm{mg}$ twice daily) on high-sensitivity C-reactive protein independent of aspirin and atorvastatin in patients with stable coronary artery disease. Am J Cardiol (2007) 99(6):805-7. doi:10.1016/j.amjcard.2006.10.039

61. Oakes PW, Patel DC, Morin NA, Zitterbart DP, Fabry B, Reichner JS, et al. Neutrophil morphology and migration are affected by substrate elasticity. Blood (2009) 114(7):1387-95. doi:10.1182/blood-2008-11-191445

62. Nam SH, Kang SG, Song SW. The neutrophil-lymphocyte ratio is associated with coronary artery calcification in asymptomatic Korean males: a crosssectional study. Biomed Res Int (2017) 2017:1989417. doi:10.1155/2017/ 1989417

63. Karaman M, Balta S, Seyit Ahmet AY, Cakar M, Naharci I, Demirkol S, et al. The comparative effects of valsartan and amlodipine on vWf levels and N/L ratio in patients with newly diagnosed hypertension. Clin Exp Hypertens (2013) 35(7):516-22. doi:10.3109/10641963.2012.758734

64. Balta S, Kurtoglu E, Kucuk U, Demirkol S, Öztürk C. Neutrophil-lymphocyte ratio as an important assessment tool. Expert Rev Cardiovasc Ther (2014) 12(5):537-8. doi:10.1586/14779072.2014.902309

65. Horne $\mathrm{BD}$, Anderson JL, John JM, Weaver A, Bair TL, Jensen KR, et al. Which white blood cell subtypes predict increased cardiovascular 
risk? JAm Coll Cardiol (2005) 45(10):1638-43. doi:10.1016/j.jacc.2005. 02.054

66. Yu XY, Li XS, Li Y, Liu T, Wang RT. Neutrophil-lymphocyte ratio is associated with arterial stiffness in postmenopausal women with osteoporosis. Arch Gerontol Geriatr (2015) 61(1):76-80. doi:10.1016/j.archger.2015.03.011

67. Wang RT, Zhang JR, Li Y, Liu T, Yu KJ. Neutrophil-lymphocyte ratio is associated with arterial stiffness in diabetic retinopathy in type 2 diabetes. J Diabetes Complications (2015) 29(2):245-9. doi:10.1016/j.jdiacomp.2014. 11.006

68. Turkmen S, Dogdu O, Tekin K, Kucukdurmaz Z, Cagliyan CE, Sarikaya S, et al. The relationship between neutrophil/lymphocyte ratio and the TIMI flow grade in patients with STEMI undergoing primary PCI. Eur Rev Med Pharmacol Sci (2013) 17:2185-9.

69. Yaman M, Arslan U, Beton O, Pamukcu HE, Dogdu O. Early and late aortic propagation velocity values in STEMI patients after successful primary PCI and their relationship with neutrophil to lymphocyte ratio. Eur Rev Med Pharmacol Sci (2016) 20(5):912-8.

70. Arbel Y, Finkelstein A, Halkin A, Birati EY, Revivo M, Zuzut M, et al. Neutrophil/lymphocyte ratio is related to the severity of coronary artery disease and clinical outcome in patients undergoing angiography. Atherosclerosis (2012) 225:456-60. doi:10.1016/j.atherosclerosis.2012.09.009

71. Kalay N, Dogdu O, Koc F, Yarlioglues M, Ardic I, Akpek M, et al. Hematologic parameters and angiographic progression of coronary atherosclerosis. Angiology (2012) 63:213-7. doi:10.1177/0003319711412763

72. Kloner RA, Giacomelli F, Alker KJ, Hale SL, Matthews R, Bellows S. Influx of neutrophils into the walls of large epicardial coronary arteries in response to ischemia/reperfusion. Circulation (1991) 84:1758-72. doi:10.1161/01. CIR.84.4.1758

73. Park BJ, Shim JY, Lee HR, Lee JH, Jung DH, Kim HB, et al. Relationship of neutrophil-lymphocyte ratio with arterial stiffness and coronary calcium score. Clin Chim Acta (2011) 412(11-12):925-9. doi:10.1016/j.cca.2011. 01.021

74. Fici F, Celik T, Balta S, Iyisoy A, Unlu M, Demitkol S, et al. Comparative effects of nebivolol and metoprolol on red cell distribution width and neutrophil/lymphocyte ratio in patients with newly diagnosed essential hypertension. J Cardiovasc Pharmacol (2013) 62(4):388-93. doi:10.1097/ FJC.0b013e31829f716a

75. Gul CB, Yildiz A, Ersoy A, Kahvecioglu S, Asiltas B, Yildirim F, et al. Correlation between arterial stiffness and inflammatory markers in autosomal dominant polycystic kidney disease patients with preserved renal function. Int Urol Nephrol (2015) 47(7):1187-94. doi:10.1007/s11255-015-1022-0

76. Tracey KJ. The inflammatory reflex. Nature (2002) 420(691):853-9. doi:10.1038/nature01321

77. Kahaleh MB, Fan PS. Effect of cytokines on the production of endothelin by endothelial cells. Clin Exp Rheumatol (1997) 15(2):163-7.

78. Cotie LM, Currie KD, McGill GM, Cameron AJ, McFadden AS, Phillips SM, et al. Associations between measures of vascular structure and function and systemic circulating blood markers in humans. Physiol Rep (2016) 4(18):e12982. doi:10.14814/phy2.12982

79. Estensen ME, Grindheim G, Remme EW, Godang K, Henriksen T, Aukrust $\mathrm{P}$, et al. Elevated inflammatory markers in preeclamptic pregnancies, but no relation to systemic arterial stiffness. Pregnancy Hypertens (2015) 5(4):325-9. doi:10.1016/j.preghy.2015.09.003

80. Dyck DJ, Heigenhauser GJ, Bruce CR. The role of adipokines as regulators of skeletal muscle fatty acid metabolism and insulin sensitivity. Acta Physiol (Oxf) (2006) 6:5-16. doi:10.1111/j.1748-1716.2005.01502.x

81. Heilbronn LK, Campbell LV. Adipose tissue macrophages, low grade inflammation and insulin resistance in human obesity. Curr Pharm Des (2008) 6:1225-30. doi:10.2174/138161208784246153

82. Koh KK, Han SH, Quon MJ. Inflammatory markers and the metabolic syndrome insights from therapeutic interventions. J Am Coll Cardiol (2005) 46:1978. doi:10.1016/j.jacc.2005.06.082

83. Tuttolomondo A, Pecoraro A, Butta C, Di Raimondo D, Ferrante A, Della Corte V, et al. Arterial stiffness indexes and serum cytokine levels in seronegative spondyloarthritis: relationships between stiffness markers and metabolic and immunoinflammatory variables. Scand J Rheumatol (2015) 44(6):474-9. doi:10.3109/03009742.2015.1030449

84. Blankenberg S, Luc G, Ducimetiere P, Arveiler D, Ferrières J, Amouyel P, et al. IL-18 and the risk of coronary heart disease in European men: the Prospective
Epidemiological Study of Myocardial Infarction (PRIME). Circulation (2003) 108:2453-9. doi:10.1161/01.CIR.0000099509.76044.A2

85. Yong K, Ooi EM, Dogra G, Mannion M, Boudville N, Chan D, et al. Elevated interleukin-12 and interleukin-18 in chronic kidney disease are not associated with arterial stiffness. Cytokine (2013) 64(1):39-42. doi:10.1016/j. cyto.2013.05.023

86. Troseid M, Seljeflot I, Weiss TW, Klemsdal TO, Hjerkinn EM, Arnesen H. Arterial stiffness is independently associated with interleukin-18 and components of the metabolic syndrome. Atherosclerosis (2010) 209:337-9. doi:10.1016/j.atherosclerosis.2009.09.028

87. Kheradmand M, Niimura H, Kuwabara K, Nakahata N, Nakamura A, Ogawa S, et al. Association of inflammatory gene polymorphysms and conventional risk factors with arterial stiffness by age. J Epidemiol (2013) 23(6):457-65. doi:10.2188/jea.JE20130054

88. Ohsaki Y, Shirakawa H, Hiwatashi K, Furukawa Y, Mizutani T, Komai M. Vitamin K suppresses lipopolysaccharide-induced inflammation in the rat. Biosci Biotechnol Biochem (2006) 70(4):926-32. doi:10.1271/bbb.70.926

89. Liuzzo G, Biasucci LM, Gallimore JR, Grillo RL, Rebuzzi AG, Pepys MB, et al. The prognostic value of $\mathrm{C}$-reactive protein and serum-amyloid a protein in severe unstable angina. N Engl J Med (1994) 331:417-24. doi:10.1056/ NEJM199408183310701

90. Ridker PM, Rifai N, Rose L, Buring JE, Cook NR. Comparison of C-reactive protein and low-density lipoprotein cholesterol levels in the prediction of first cardiovascular events. N Engl J Med (2002) 347:1557-65. doi:10.1056/ NEJMoa021993

91. Ridker PM, Buring JE, Cook NR, Rifai N. C-reactive protein, the metabolic syndrome, and risk of incident cardiovascular events: an 8-year follow-up of 14,719 initially healthy American women. Circulation (2003) 107:391. doi:10.1161/01.CIR.0000055014.62083.05

92. Ridker PM. Clinical application of C-reactive protein for cardiovascular disease detection and prevention. Circulation (2003) 107(3):363-9. doi:10.1161/01.CIR.0000053730.47739.3C

93. Tan KC, Chow WS, Tam SC, Ai VH, Lam CH, Lam KS. Atorvastatin lowers C-reactive protein and improves endothelium-dependent vasodilation in type 2 diabetes mellitus. JClin Endocrinol Metab (2002) 87:563-8. doi:10.1210/jcem.87.2.8249

94. Brevetti G, Silvestro A, Di Giacomo S, Bucur R, Di Donato A, Schiano V, et al. Endothelial dysfunction in peripheral arterial disease is related to increase in plasma markers of inflammation and severity of peripheral circulatory impairment but not to classic risk factors and atherosclerotic burden. J Vasc Surg (2003) 38:374-9. doi:10.1016/S0741-5214(03)00124-1

95. Prasad A, Zhu J, Halcox JP, Waclawiw MA, Epstein SE, Quyyumi AA. Predisposition to atherosclerosis by infections: role of endothelial dysfunction. Circulation (2002) 106:184-90. doi:10.1161/01.CIR.0000021125. 83697.21

96. Van Haelst PL, van Doormaal JJ, Asselbergs FW, van Roon AM, Veeger NJ, Henneman MM, et al. Correlates of endothelial function and their relationship with inflammation in patients with familial hypercholesterolaemia. Clin Sci (Lond) (2003) 104:627-32. doi:10.1042/CS20020293

97. Salomaa V, Riley W, Kark JD, Nardo C, Folsom AR. Noninsulin-dependent diabetes mellitus and fasting glucose and insulin concentrations are associated with arterial stiffness indexes. The ARIC Study. Atherosclerosis Risk in CommunitiesStudy.Circulation (1995)91:1432-43. doi:10.1161/01.CIR.91.5.1432

98. Mattace-Raso FU, van der Cammen TJ, van der Meer IM, Schalekamp MA, Asmar R, Hofman A, et al. C-reactive protein and arterial stiffness in older adults: the Rotterdam Study. Atherosclerosis (2004) 176(1):111-6. doi:10.1016/j.atherosclerosis.2004.04.014

99. Kullo IJ, Seward JB, Bailey KR, Bielak LF, Grossardt BR, Sheedy PF II, et al. C-reactive protein is related to arterial wave reflection and stiffness in asymptomatic subjects from the community. Am JHypertens (2005) 18(8):1123-9. doi:10.1016/j.amjhyper.2005.03.730

100. McEniery CM, Spratt M, Munnery M, Yarnell J, Lowe GD, Rumley A, et al. An analysis of prospective risk factors for aortic stiffness in men: 20-year follow-up from the Caerphilly prospective study. Hypertension (2010) 56:36-43. doi:10.1161/HYPERTENSIONAHA.110.150896

101. Tomiyama H, Arai T, Koji Y, Yambe M, Hirayama Y, Yamamoto Y, et al. The relationship between high-sensitive $\mathrm{C}$ reactive protein and pulse wave velocity in healthy Japanese men. Atherosclerosis (2004) 174:373-7. doi:10.1016/j. atherosclerosis.2004.01.032 
102. Gurlek Demirci B, Sezer S, Colak T, Sayin CB, Tutal E, Haberal M. Posttransplant C-reactive protein predicts arterial stiffness and graft function in renal transplant recipients. Transplant Proc (2015) 47:1174-7. doi:10.1016/j. transproceed.2014.10.064

103. Kampus P, Kals J, Ristimäe T, Fischer K, Zilmer M, Teesalu R. Highsensitivity C-reactive protein affects central haemodynamics and augmentation index in apparently healthy persons. J Hypertens (2004) 22(6):1133-9. doi:10.1097/00004872-200406000-00014

104. Nurizal A, Antono D, Wijaia IP, Shatri H. Correlation between highsensitivity $\mathrm{C}$ reactive protein and local arterial stiffness measured by radio frequency echotracking system in type 2 diabetic patients. Acta Med Indones (2014) 46(4):308-13.

105. Dörr O, Liebetrau C, Möllmann H, Gaede L, Troidl C, Rixe J, et al. Soluble fms-like tyrosine kinase- 1 and endothelial adhesion molecules (intercellular cell adhesion molecule-1 and vascular cell adhesion molecule-1) as predictive markers of blood pressure reduction after renal sympathetic denervation. Hypertension (2014) 63:984-90. doi:10.1161/HYPERTENSIONAHA. 113.02266

106. Kunutsor SK, Bakker SJL, Dullaart RPF. Soluble vascular cell adhesion molecules may be protective of future cardiovascular disease risk: findings from the PREVEND prospective cohort study. J Atheroscler Thromb (2017) 24:804-18. doi:10.5551/jat.38836

107. Blankenberg S, Rupprecht HJ, Bickel K, Peetz D, Hafner G, Tiret L, et al. Circulating cell adhesion molecules and death in patients with coronary artery disease. Circulation (2001) 104(12):1336-42. doi:10.1161/hc3701.095949

108. Preedy VR. Adhesion Molecules. Enfield, New Hampshire: CRC Press (2016). $534 \mathrm{p}$.

109. Kilic ID, Findikoglu G, Alihanoglu YI, Yildiz BS, Uslu S, Rota S, et al. Circulating adhesion molecules and arterial stiffness. Cardiovasc J Afr (2015) 26(1):21-4. doi:10.5830/CVJA-2014-060

110. Kals J, Kampus P, Kals M, Pulges A, Teesalu R, Zilmer K, et al. Inflammation and oxidative stress are associated differently with endothelial function and arterial stiffness in healthy subjects and in patients with atherosclerosis. Scand J Clin Lab Invest (2008) 68(7):594-601. doi:10.1080/00365510801930626

111. Boomsma F, Hut H, Bagghoe U, van der Houwen A, van den Meiracker A. Semicarbazide-sensitive amine oxidase (SSAO): from cell to circulation. Med Sci Monit (2005) 11(4):RA122-6.

112. Chen DW, Zhao RM, Jin Y, Zhang J, Han C, Jiang SQ, et al. Plasma soluble vascular adhesion protein-1 concentration correlates with arterial stiffness: a cross-sectional study. Arch Gerontol Geriatr (2015) 61:67-71. doi:10.1016/j. archger.2015.04.007

113. Merinen $M$, Irjala $H$, Salmi $M$, Jaakkola I, Hänninen A, Jalkanen S. Vascular adhesion protein-1 is involved in both acute and chronic inflammation in the mouse. Am J Pathol (2005) 166(3):793-800. doi:10.1016/ S0002-9440(10)62300-0

114. Jalkanen S, Karikoski M, Mercier N, Koskinen K, Henttinen T, Elima K, et al. The oxidase activity of vascular adhesion protein-1 (VAP-1) induces endothelial E- and P-selectins and leukocyte binding. Blood (2007) 110(6):1864-70. doi:10.1182/blood-2007-01-069674

115. Mattila KJ, Nieminen MS, Valtonen VV, Rasi VP, Kesäniemi YA, Syrjälä SL, et al. Association between dental health and acute myocardial infarction. BMJ (1989) 298:779-81. doi:10.1136/bmj.298.6676.779

116. Syrjanen J, Peltola J, Valtonen V, Iivanainen M, Kaste M, Huttunen JK. Dental infections in association with cerebral infarction in young and middleaged men. J Intern Med (1989) 225:179-84. doi:10.1111/j.1365-2796.1989. tb00060.x

117. Franek E, Januszkiewicz-Caulier J, Blach A, Napora M, Jedynasty K, Budlewski T, et al. Intima-media thickness and other markers of atherosclerosis in patients with type 2 diabetes and periodontal disease. Kardiol Pol (2012) 70(1):7-13

118. Piepoli MF, Hoes AW, Agewall S, Albus C, Brotons C, Catapano AL, et al. 2016 European Guidelines on cardiovascular disease prevention in clinical practice: the Sixth Joint Task Force of the European Society of Cardiology and Other Societies on cardiovascular disease prevention in clinical practice (constituted by representatives of 10 societies and by invited experts) developed with the special contribution of the European Association for Cardiovascular Prevention and Rehabilitation (EACPR). Atherosclerosis (2016) 252:207-74. doi:10.1016/j.atherosclerosis.2016.05.037
119. Nazir MA. Prevalence of periodontal disease, its association with systemic diseases and prevention. In J Health Sci (Qassim) (2017) 11(2):72-80.

120. Janket SJ, Baird AE, Chuang SK, Jones JA. Meta-analysis of periodontal disease and risk of coronary heart disease and stroke. Oral Surg Oral Med Oral Pathol Oral Radiol Endod (2003) 95(5):559-69. doi:10.1067/moe. 2003.107

121. Slocum C, Kramer C, Genco CA. Immune dysregulation mediated by the oral microbiome: potential links to chronic inflammation and atherosclerosis. J Intern Med (2016) 280(1):114-28. doi:10.1111/joim.12476

122. Van Dyke TE, Serhan CN. Resolution of inflammation: a new paradigm for the pathogenesis of periodontal diseases. J Dent Res (2003) 82(2):82-90. doi:10.1177/154405910308200202

123. Hasturk H, Kantarci A. Activation and resolution of periodontal inflammation and its systemic impact. Periodontol 2000 (2015) 69(1):255-73. doi:10.1111/prd.12105

124. Gurav AN. The association of periodontitis and metabolic syndrome. Dent Res J (Isfahan) (2014) 11(1):1-10.

125. Mozos I. Pathophysiology. Lecture Notes for Dental Medicine. Saarbrücken, Deutschland: LAP Lambert Academic Publishing (2015). 296 p.

126. Beck JD, Eke P, Lin D, Madianos P, Couper D, Moss K, et al. Associations between IgG antibody to oral organisms and carotid intima-medial thickness in community-dwelling adults. Atherosclerosis (2005) 183:342-8. doi:10.1016/j.atherosclerosis.2005.03.017

127. Desvarieux M, Demmer RT, Jacobs DR, Papapanou PN, Sacco RL, Rundek T. Changes in clinical and microbiological periodontal profiles related to the progression of carotid intima-media thickness: the oral infections and vascular disease epidemiology study. J Am Heart Assoc (2013) 2:e000254. doi:10.1161/JAHA.113.000254

128. Zaremba M, Gorska R, Suwalski P, Kowalski J. Evaluation of the incidence of periodontitis associated bacteria in the atherosclerotic plaque of coronary blood vessels. J Periodontol (2007) 78:322-7. doi:10.1902/jop.2006.060081

129. Hayashida H, Saito T, Kawasaki K, Kitamura M, Furugen R, Iwasaki T, et al. Association of periodontitis with carotid artery intima-media thickness and arterial stiffness in community-dwelling people in Japan: the Nagasaki Islands study. Atherosclerosis (2013) 229(1):186-91. doi:10.1016/j. atherosclerosis.2013.04.002

130. Shanker J, Setty P, Arvind P, Nair J, Bhasker D, Balakrishna G, et al. Relationship between periodontal disease, Porphyromonas gingivalis, peripheral vascular resistance markers and coronary artery disease in Asian Indians. Thromb Res (2013) 132(1):e8-14. doi:10.1016/j.thromres.2013.04.023

131. Kapellas K, Jamieson LM, Do LG, Bartold PM, Wang H, Maple-Brown LJ, et al. Associations between periodontal disease and cardiovascular surrogate measures among Indigenous Australians. Int J Cardiol (2014) 173(2):190-6. doi:10.1016/j.ijcard.2014.02.015

132. Jockel-Schneider Y, Harks I, Haubitz I, Fickl S, Eigenthaler M, Schlagenhauf U, et al. Arterial stiffness and pulse wave reflection are increased in patients suffering from severe periodontitis. PLoS One (2014) 9(8):e103449. doi:10.1371/journalone.0103449

133. Schmitt A, Carra MC, Boutouyrie P, Bouchard P. Periodontitis and arterial stiffness: a systematic review and meta-analysis. J Clin Periodontol (2015) 42(11):977-87. doi:10.1111/jcpe.12467

134. Houcken W, Teeuw WJ, Bizzaro S, Alvarez Rodriguez E, Mulders TA, van den Born BJ, et al. Arterial stiffness in periodontitis patients and controls. A case-control and pilot intervention study. JHum Hypertens (2016) 30(1):24-9. doi:10.1038/jhh.2015.41

135. Vidal F, Cordovil I, Figueredo CM, Fischer RG. Non-surgical periodontal treatment reduces cardiovascular risk in refractory hypertensive patients: a pilot study. J Clin Periodontol (2013) 40(7):681-7. doi:10.1111/jcpe.12110

136. Sanz-Miralles EC, Li R, Momen-Heravi F, Mendieta C, Konofagou EE, Papapanou PN. Assessment of arterial stiffness in periodontitis using a novel pulse wave imaging methodology. JClin Periodontol (2017) 44(5):502-10. doi:10.1111/jcpe.12717

137. Harris TA, Yamakuchi M, Ferlito M, Mendell JT, Lowenstein CJ. MicroRNA-126 regulates endothelial expression of vascular cell adhesion molecule 1. Proc Natl Acad Sci U S A (2008) 105(5):1516-21. doi:10.1073/ pnas. 0707493105

138. Zhou J, Wang KC, Wu W, Subramaniam S, Shyy JY, Chiu JJ, et al. MicroRNA-21 targets peroxisome proliferators activated receptor- $\alpha$ in an autoregulatory 
loop to modulate flow-induced endothelial inflammation. Proc Natl Acad Sci U S A (2011) 108(25):10355-60. doi:10.1073/pnas.1107052108

139. Parthenakis F, Marketou M, Kontaraki J, Patrianakos A, Nakou H, Touloupaki M, et al. Low levels of microRNA-21 are a marker of reduced arterial stiffness in well-controlled hypertension. J Clin Hypertens (Greenwich) (2017) 19(3):235-40. doi:10.1111/jch.12900

140. Lin X, Zhan JK, Wang YJ, Tan P, Chen YY, Deng HQ, et al. Function, role, and clinical application of microRNAs in vascular aging. Biomed Res Int (2016) 2016:6021394. doi:10.1155/2016/6021394

141. Fiedler J, Thum T. MicroRNAs in myocardial infarction. Arterioscler Thromb Vasc Biol (2013) 33(2):201-5. doi:10.1161/ATVBAHA.112.300137

142. Qin B, Yang H, Xiao B. Role of microRNAs in endothelial inflammation and senescence. Mol Biol Rep (2012) 39(4):4509-18. doi:10.1007/ s11033-011-1241-0

143. Ni CW, Qiu H, Jo H. MicroRNA-663 upregulated by oscillatory shear stress plays a role in inflammatory response of endothelial cells. Am J Physiol Heart Circ Physiol (2011) 300(5):H1762-9. doi:10.1152/ajpheart.00829.2010

144. Liao YC, Wang YS, Guo YC, Lin WL, Chang MH, Juo SH. Let-7g improves multiple endothelial functions through targeting transforming growth factor-beta and SIRT-1 signaling. J Am Coll Cardiol (2014) 63(16):1685-94. doi:10.1016/j.jacc.2013.09.069

145. Ding Y, Sun X, Shan PF. MicroRNAs and cardiovascular disease in diabetes mellitus. Biomed Res Int (2017) 2017:4080364. doi:10.1155/2017/ 4080364

146. Loyer X, Potteaux S, Vion AC, Guérin CL, Boulkroun S, Rautou PE, et al. Inhibition of microRNA-92a prevents endothelial dysfunction and atherosclerosis in mice. Circ Res (2014) 114(3):434-43. doi:10.1161/CIRCRESAHA. 114.302213

147. Canfran-Duque A, Rotllan N, Zhang X, Fernández-Fuertes M, RamírezHidalgo C, Araldi E, et al. Macrophage deficiency of miR-21 promotes apoptosis, plaque necrosis, and vascular inflammation during atherogenesis. EMBO Mol Med (2017):e201607492. doi:10.15252/emmm.201607492

148. Demolli S, Doebele C, Doddaballapur A, Lang V, Fisslthaler B, Chavakis E, et al. MicroRNA-mediates anti-inflammatory effects of shear stress and KLF2 via repression of angiopoietin 2. J Moll Cell Cardiol (2015) 88:111-9. doi:10.1016/j.yjmcc.2015.10.009

149. Deng H, Song Z, Xu H, Deng X, Zhang Q, Chen H, et al. MicroRNA-1185 promotes arterial stiffness though modulating VCAM-1 and E-selectin. Cell Physiol Biochem (2017) 41(6):2183-93. doi:10.1159/000475576

150. Martinez-Gonzalez J, Badimon L. Mechanisms underlying the cardiovascular effects of COX-inhibition: benefits and risks. Curr Pharm Des (2007) 13(22):2215-27. doi:10.2174/138161207781368774

151. Capriotti T, Parker Frizzell J. Pathophysiology. Introductory Concepts and Clinical Perspectives. Philadelphia: FA Davis Company (2016). 1161 p.

152. Korotkova M, Jakobsson PJ. Characterization of microsomal prostaglandin E synthase 1 inhibitors. Basic Clin Pharmacol Toxicol (2014) 114(1):64-9. doi:10.1111/bcpt.12162
153. Psarra A, Nikolaou A, Kokotou MG, Limnios D, Kokotos G. Microsomal prostaglandin E2 synthase-1 inhibitors: a patent review. Expert Opin Ther Pat (2017) 27(9):1047-59. doi:10.1080/13543776.2017.1344218

154. Dieffenbach PB, Mallarino Haeger C, Coronata AMF, Choi KM, Varelas X, Tschumperlin DJ, et al. Arterial stiffness induces remodeling phenotypes in pulmonary artery smooth muscle cells via YAP/TAZ-mediated repression of cyclooxygenase-2. Am J Physiol Lung Cell Mol Physiol (2017). doi:10.1152/ ajplung.00173.2017

155. Fredenburgh LE, Liang OD, Macias AA, Polte TR, Liu X, Riascos DF, et al. Absence of cyclooxigenase-2 exacerbates hypoxia-induced pulmonary hypertension and enhances contractility of vascular smooth muscle cells. Circulation (2008) 117(16):2114-22. doi:10.1161/CIRCULATIONAHA.107. 716241

156. Liu C, Gao J, Chen B, Chen L, Belguise K, Yu W, et al. Cyclooxygenase-2 promotes pulmonary intravascular macrophage accumulation by exacerbating BMP signaling in rat experimental hepatopulmonary syndrome. Biochem Pharmacol (2017) 138:205-15. doi:10.1016/j.bcp.2017.06.117

157. Avendano MS, Martinez-Revelles S, Aguado A, Simões MR, GonzálezAmor M, Palacios R, et al. Role of COX-2-derived PGE2 on vascular stiffness and function in hypertension. Br J Pharmacol (2016) 173(9):1541-55. doi:10.1111/bph.13457

158. Vlachopoulos C, Aznaouridis K, Bratsas A, Ioakeimidis N, Dima I, Xaplanteris $\mathrm{P}$, et al. Arterial stiffening and systemic endothelial activation induced by smoking: the role of COX-1 and COX-2. Int J Cardiol (2015) 189:293-8. doi:10.1016/j.ijcard.2015.04.029

159. Wong M, Jiang BY, McNeill K, Farish S, Kirkham B, Chowienczyk P. Effects of selective and non-selective cyclooxygenase inhibition on endothelial function in patients with rheumatoid arthritis. Scand J Rheumatol (2007) 36(4):265-9. doi:10.1080/03009740701286771

160. Laurent S, Fassot C, Lacolley P, Boutouyrie P. Molecular determinants of arterial stiffness. Artery Res (2007) 1:26-31. doi:10.1016/j. artres.2007.03.004

161. Chen Y, Shen F, Liu J, Yang G. Arterial stiffness and stroke: de-stiffening strategy, a therapeutic target for stroke. Stroke Vasc Neurol (2017):e000045. doi:10.1136/svn-2016-000045

Conflict of Interest Statement: The authors declare that the research was conducted in the absence of any commercial or financial relationships that could be construed as a potential conflict of interest.

Copyright $\odot 2017$ Mozos, Malainer, Horbańczuk, Gug, Stoian, Luca and Atanasov. This is an open-access article distributed under the terms of the Creative Commons Attribution License (CC BY). The use, distribution or reproduction in other forums is permitted, provided the original author(s) or licensor are credited and that the original publication in this journal is cited, in accordance with accepted academic practice. No use, distribution or reproduction is permitted which does not comply with these terms. 